\title{
Sedimentology, diagenesis and ichnology of Cretaceous and Palaeogene calcretes and palustrine carbonates from Uruguay
}

\author{
Ana M. Alonso-Zarza ${ }^{\mathrm{a}, *}$, Jorge F. Genise ${ }^{\mathrm{b}}$, Mariano Verde ${ }^{\mathrm{c}}$ \\ a Dept. Petrología y Geoquímica, Fac. CC. Geológicas, IGE-CSIC, Universidad Complutense, 28040 Madrid, Spain \\ b CoNICET, División Icnología, Museo Argentino de Ciencias Naturales, Angel Gallardo 470, 1405 Buenos Aires, Argentina \\ c SNI-ANII Departamento de Evolución de Cuencas, Facultad de Ciencias, Universidad de la República, Montevideo, Uruguay
}

Keywords:

Calcretes

Lacustrine carbonates

Trace fossils

Silicification

Chaco-Paranense Basin

Uruguay

\begin{abstract}
A B S T R A C T
The Cretaceous (Mercedes Formation) and Paleogene (Queguay Formation) deposits cropping out in W and S Uruguay comprise two terrestrial limestone units that are very rich in trace fossils. The study of these units permits to propose a sedimentological model for palustrine limestones and calcretes in which the distribution of different types of trace fossils is considered. The study units include three main types of deposit: lacustrine limestones, palustrine limestones and calcretes. The lacustrine limestones are relatively homogeneous and contain gastropods, charophytes and ostracods, but no trace fossils. They were deposited in a relatively more perennial lacustrine environment. The palustrine limestones include four different facies: desiccated mudstones, nodular limestones, granular limestones and gravel-sheets. The desiccated mudstones indicate a lesser degree of pedogenic modification and the granular limestones a higher degree. The gravel-sheets are an indication of the reworking of previous limestones deposits during low lakewater levels. Most of the palustrine limestones (except the gravel sheets) contain the same bioclasts as the lacustrine limestones plus a variety of trace fossils such as Rebuffoichnus sciuttoi, Fictovichnus gobiensis and different ichnospecies of Celliforma. The calcretes are either massive (groundwater) or laminar. The massive calcretes are sandy limestones made up of a carbonate matrix and cements. The laminar calcretes (root mats), which contain alveolar septal structures, occur as centimetre-thick layers and can be seen in all types of deposit. They contain the same trace fossil association as the palustrine limestones; the massive calcretes are poorer in such fossils. The distribution of trace fossils in these environments is under strong facies control and provides good evidence of subaerial exposure and semi-arid climates. All the limestones are partially replaced and cemented by opal and quartz, but in all cases the primary structure is preserved. Silicification occurred under groundwater meteoric conditions. Overall, the limestones facies (calcretes, palustrine and lacustrine) and their lateral distribution likely reflect the existence of wetland environments in semiarid to sub-humid climates. These climatic conditions were interrupted by a period of increased precipitations, probably the Early Eocene Climatic Optimum.
\end{abstract}

\section{Introduction}

Insect trace fossils are abundant in palustrine deposits and calcretes. This is particularly true in South America (Genise et al., 2010) e.g., in the Palaeogene palaeosols of the Gran Salitral and Sarmiento Formations in Argentina (Melchor et al., 2002; Bellosi et al., 2010). Other well-known palustrine and calcrete deposits that contain insect traces include the Pleistocene Bridgewater Formation in Australia (Houston, 1987), the Bembridge Formation of the Isle of White (Edwards et al., 1998), the Oligocene Brulle Formation of South Dakota (USA) (Retallack, 1984), and the calcretes of the Canary

\footnotetext{
* Corresponding author.

E-mail address: alonsoza@geo.ucm.es (A.M. Alonso-Zarza).
}

Islands (Alonso-Zarza and Silva, 2002; Genise and Edwards, 2003). In contrast, in many well-described palustrine and calcrete deposits, such as in the Cretaceous Rupelo Formation in the Cameros Basin (Platt, 1989) or in the Tertiary Duero Basin in Spain (Huerta and Armenteros, 2005), insect trace fossils are not recorded. This may reflect environmental conditions that were unsuitable for insects, or more simply that there have been few searches for such trace fossils. Although Freytet and Plaziat (1982) give some initial clues on the distribution of some of these traces in palustrine carbonates and carbonate palaeosols, most environmental models (e.g., Freytet and Verrecchia, 2002; Alonso-Zarza, 2003; and Wright, 2007) do not discuss in detail the distribution or types of trace fossils found in such settings. However, in the last decade, ichnology in continental settings has advanced notably, and a recurrent trace fossil association dominated by insect traces (the Celliforma ichnofacies) seems to be 
indicative of carbonate palaeosols bearing low plant densities under conditions of arid to semiarid environments (Genise et al., 2010). Thus, these traces can provide data of use in interpreting the palaeoenvironment of the basins in which calcretes and palustrine carbonates form.

The Cretaceous and Palaeogene of $W$ and S Uruguay are represented by two units formed by continental limestones with an exceptional abundance of trace fossils. These units crop out in Uruguay and (sparsely) in NW rgentina within the Chaco-Paranense and Santa Lucía Basins (Fig. 1). There is an agreement, based on the overall geological setting and the fossil content, that the age of these limestones ranges from Late Cretaceous to Eocene and that they undoubtedly represent continental limestones formed in arid to semiarid climates (Goso and Bossi, 1966; Bossi et al., 1975; Sprechmann et al., 1981; GosoAguilar, 1999; Daners and Guerstein, 2004; and Martínez and Veroslavsky, 2004). However discrepancies exist in their environmental interpretation. Earlier authors interpreted these limestones to have been deposited in lacus rine environments (Lambert, 1939; Serra, 1945; and Jones, 1956), whereas more recently they have been interpreted as thick groundwater calcretes (Sprechmann et al., 1981; Bossi and
Navarro, 1991; Veroslavsky and Martínez, 1996; Martínez et al., 1997. 2001; and Martínez and Veroslavslyy, 2004). Tófalo and Morrás (2009) and Tófalo and Pazos (2010) interpret these limestones as a wide variety of carbonates, including calcretes and palustrine limestones.

The aims of this work are: 1) to establish the stratigraphic framework for these limestones, 2) to determine the processes and palaeoenvironments involved in the formation of these carbonates, 3) to record the distribution of the different types of trace fossils and the slight differences in the sedimentary environment that can control the occurrence of them, 4) to analyse the silicification processes that these limestones underwent, and 5) to propose the palaeogeographic setting that prevailed during part of the Cretaceous and Palaeogene. In doing so we will try to show that the traces fossils are a useful tool to understand the sedimentary record of continental carbonates and its paleoclimatic constraints.

\section{Geological setting}

The carbonates studied in this paper form part of the sedimentary record of the Chaco-Paranense and Santa Lucía Basins (Fig. 1) that
A

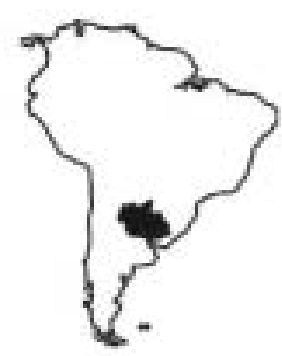

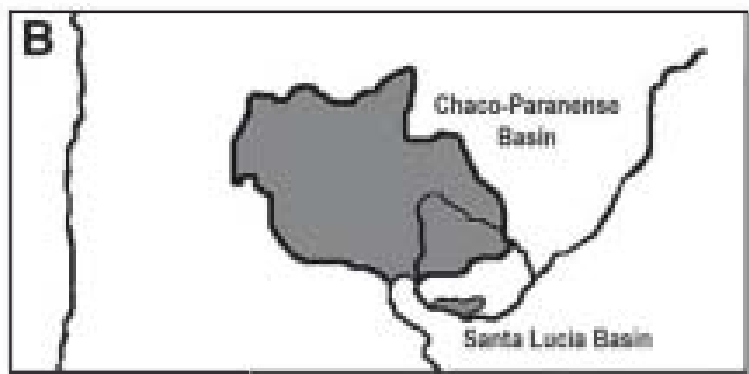

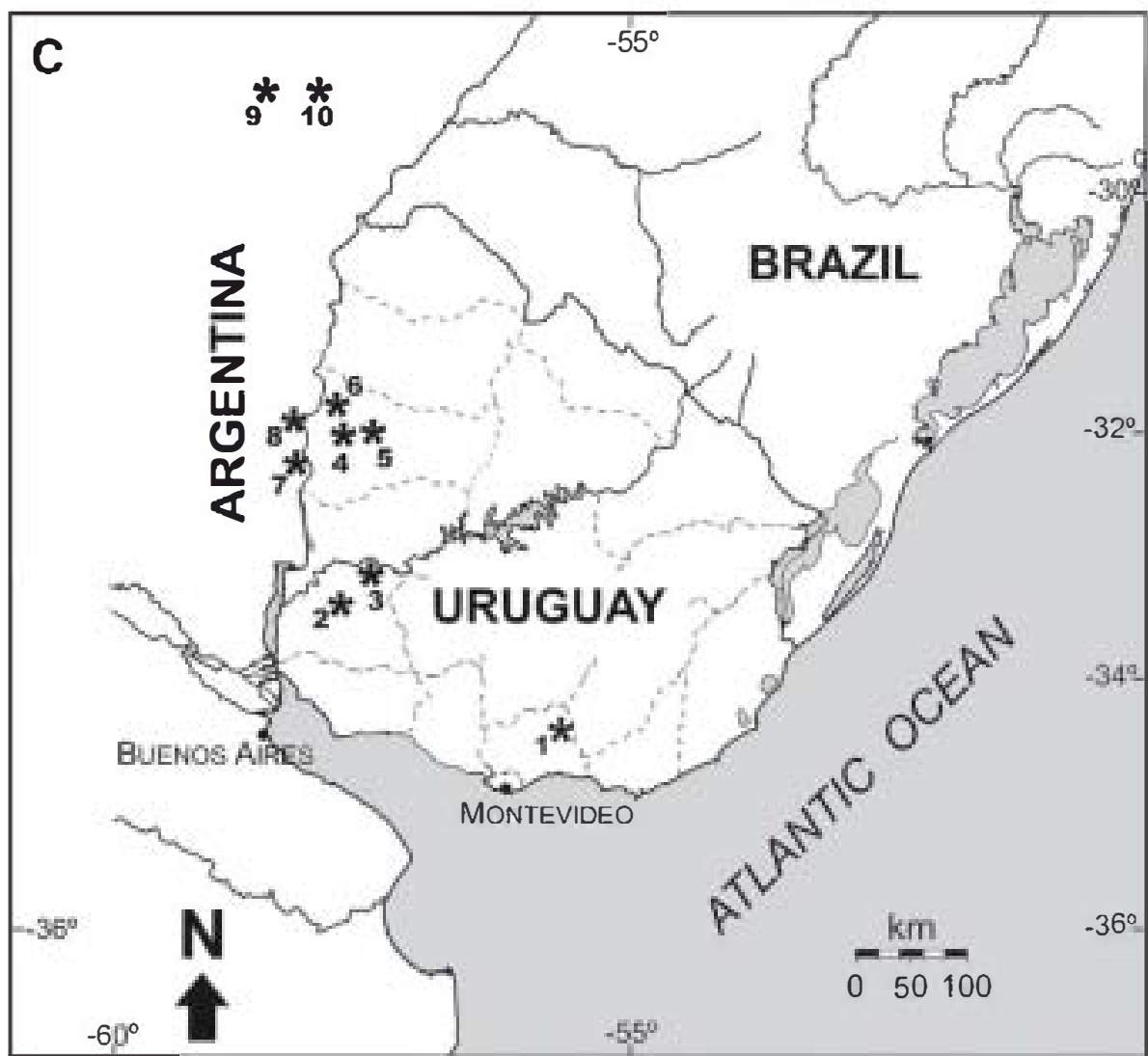

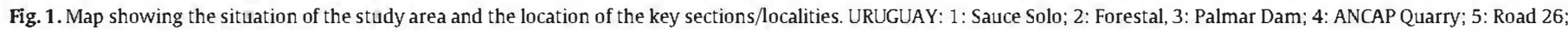
6: Quebracho. ARGENTINA: 7: Colón. 8: PN El Palmar; 9: Arroyo Itá; 10: Road 40, Northeastern of Mercedes city. 
Table 1

Historical review about the nomenclature, lithostratigraphic treatment and age given to the "Calizas del Queguay".

\begin{tabular}{|c|c|c|}
\hline Authors & Nomenclature & Age \\
\hline Frenguelli (1930) & $\begin{array}{l}\text { Silicified deposits of Quebracho } \\
\text { (N) and Limestones with } \\
\text { Strophocheilus from Migues (S) }\end{array}$ & Tertiary \\
\hline Walther (1931) & "Calizas silíceas" & Mio-Pliocene \\
\hline Lambert (1940a) & "Calizas lacustres de Queguay" & $\begin{array}{l}\text { Cretaceous-Tertiary- } \\
\text { Oligocene }\end{array}$ \\
\hline Lambert (1940b) & “Calizas de Queguay' & $\begin{array}{l}\text { Cretaceous-Tertiary- } \\
\text { Oligocene }\end{array}$ \\
\hline Serra (1945) & “Calizas de Queguay' & Oligocene \\
\hline Jones (1956) & "Calizas de Queguay" & Oligocene \\
\hline $\begin{array}{l}\text { Caorsi and Goñi } \\
\text { (1958) }\end{array}$ & "Calizas del Queguay" & Oligocene \\
\hline $\begin{array}{l}\text { Goso and Bossi } \\
\text { (1966) }\end{array}$ & Queguay Formation & Paleogene \\
\hline Bossi (1966) & Queguay Formation & Cenozoic \\
\hline Bossi et aL (1975) & Mercedes Formation & Cretaceous \\
\hline Mones (1979) & Queguay Formation & Late Eocene \\
\hline $\begin{array}{l}\text { Sprechmann et aL } \\
\text { (1981) }\end{array}$ & $\begin{array}{l}\text { Queguay Formation, } \\
\text { Mercedes Formation }\end{array}$ & Cretaceous-Paleogene \\
\hline Preciozzi et al. (1985) & Mercedes Formation & Late Cretaceous \\
\hline $\begin{array}{l}\text { Bossi and Navarro } \\
\text { (1991) }\end{array}$ & Mercedes Formation & Cretaceous \\
\hline $\begin{array}{l}\text { Veroslavsky and } \\
\text { Martínez (1996) }\end{array}$ & "Calizas del Queguay" & Middle Paleocene \\
\hline Martínez et aL (1997) & "Calizas del Queguay" & Paleocene \\
\hline Martínez et aL (2001) & "Calizas del Queguay" & Paleocene \\
\hline Tofalo et aL (2001) & Queguay Formation & $\begin{array}{l}\text { Late Cretaceous-Early } \\
\text { Eocene }\end{array}$ \\
\hline $\begin{array}{l}\text { Goso-Aguilar and } \\
\text { Perea (2003) }\end{array}$ & $\begin{array}{l}\text { "Queguay Chemostratigraphic } \\
\text { Unit" }\end{array}$ & Paleocene \\
\hline $\begin{array}{l}\text { Martínez and } \\
\text { Veroslavsky (2004) }\end{array}$ & $\begin{array}{l}\text { Queguay or Calizas del } \\
\text { Queguay Formation }\end{array}$ & Paleocene (Middle-Iate) \\
\hline $\begin{array}{l}\text { Veroslavsky and De } \\
\text { Santa Ana (2004) }\end{array}$ & "Calizas del Queguay" & Paleocene (Middle-Iate) \\
\hline $\begin{array}{l}\text { Tófalo and Morrás } \\
\text { (2009) }\end{array}$ & "Formación Queguay" & Paleocene \\
\hline $\begin{array}{l}\text { Tófalo and Pazos } \\
\text { (2010) }\end{array}$ & Queguay Formation & Paleocene \\
\hline
\end{tabular}

overlie the Uruguayan shield. These carbonates were mentioned in the diaries of Charles Darwin and Priest Dámaso Antonio Larrañaga at the end of the nineteenth century. These rocks crop out mainly in the north-western region of Uruguay, in Paysandú, Rio Negro and Soriano Counties, and to a lesser extent near Montevideo, in southern Uruguay. Their first detailed description was provided by Frenguelli (1930), who also correlated the deposits from north-western Uruguay with those located about $300 \mathrm{~km}$ away in southern Uruguay. Frenguelli (1930) recorded the presence of the gastropods Bulimulus and Planorbis at Estación Quebracho and discussed the fossil content, including cells from "solitary vespids". The name "Calizas del Queguay" was first used by Lambert (1940a).

The stratigraphy of these basins has been widely discussed and there is no general agreement on the age or even the lithology of some of the units, especially for certain formations. Table 1 summarizes all the previous stratigraphic work performed on these limestones and reflects the lack of agreement regarding their age and stratigraphic position.

The lowermost sedimentary unit is the Guichón Formation or "Areniscas de Guichón" (Lambert 1940a), which overlies the Serra Geral Basalts. There is a general agreement on the Cretaceous age and composition of this unit which is formed by up to $100 \mathrm{~m}$ of coarse sandstones (Goso-Aguilar and Perea, 2003; Tófalo and Pazos, 2010). The overlying formation is the Mercedes Formation, which is also Cretaceous in age and composed of a fining upwards sequence including conglomerates, sandstones, and rare mudstones. Both the Guichón and Mercedes Formations are interpreted as fluvial deposits (Chebli et al., 1989; Tófalo and Pazos, 2010). Bossi (1966) included the Queguay limestones at the top of - but still within - the Cretaceous Mercedes Formation. The Mercedes Formation is overlain by the Asencio Formation, which is a distinctive, red-coloured sandstone with a representative ichnofauna of the Coprinisphaera ichnofacies, and which is interpreted as a sequence of mature ultisols that developed under warm and humid conditions (Roselli, 1939; González, 1999; and Bellosi et al., 2004). The Cenozoic Fray Bentos Formation overlies the Asencio Formation and consists of sandstones and mudstones (brown in colour), containing palaeosols (Tófalo and

Table 2

Studied sections/localities with indications of the formation they belong and their fossil content.

\begin{tabular}{|c|c|c|c|}
\hline Iocality/GPS & Formation/age & Trace fossils & Body fossils \\
\hline $\begin{array}{l}\text { El Palmar Dam (Uruguay) } \\
\text { S } 33^{\circ} 6^{\prime} 23.24^{\prime \prime} \text {; W } 57^{\circ} 28^{\prime} 19.50^{\prime \prime}\end{array}$ & $\begin{array}{l}\text { Mercedes Formation (Upper } \\
\text { Cretaceous) }\end{array}$ & $\begin{array}{l}\text { Celliform spirifer, Celliforma germanica, } \\
\text { Fictovichnus gobiensis, rhizoliths }\end{array}$ & Biomphalaria, characean oogonia. \\
\hline Quebracho railway cut (Uruguay) & Queguay Formation (Middle & C. spirifer, C germanica, Celliforma roseliii, & Biomphalaria, Physa, Eoborus. \\
\hline $\mathrm{S} 31^{\bullet} 55^{\prime} 19.6^{\prime \prime} \mathrm{W} 57^{\bullet} 54^{\prime} 24.7^{\prime \prime}$ & Eocene-Middle Oligocene) & Rebuffoichnus sciuttoi, Rhizoliths & Celtis endocarps, characean oogonia. \\
\hline $\begin{array}{l}\text { Forestal Caja Bancaria Quarry (Uruguay) } \\
\qquad 332^{\circ} 27^{\prime} 44.0^{\prime \prime} \mathrm{W}^{\circ} 37^{\circ} 25.2^{\prime \prime}\end{array}$ & $\begin{array}{l}\text { Mercedes Formation (Upper } \\
\text { Cretaceous) }\end{array}$ & $\begin{array}{l}\text { F. gobiensis, C spirifer, C germanica, } \\
\text { rhizoliths }\end{array}$ & $\begin{array}{l}\text { Biomphalaria, Physa, wood remains, characean } \\
\text { oogonia, dinosaur eggshells (Sphaerovum } \\
\text { erbeni) }\end{array}$ \\
\hline $\begin{array}{l}\text { Ia Sota Ranch Quarry (Uruguay) } \\
\text { S32 } 02^{\prime} 37.0^{\prime \prime} \text { W5 } 57^{\circ} 36^{\prime} 38.2^{\prime \prime}\end{array}$ & & $\begin{array}{l}\text { C. spirifer, C germanica, F gobiensis, } \\
\text { rhizoliths }\end{array}$ & Pupillidae indet. \\
\hline $\begin{array}{l}\text { Road } 26, \mathrm{Km} 49 \text { (Uruguay) } \\
\mathrm{S} 32^{\circ} 03^{\prime} 30.4^{\prime \prime} \mathrm{W}^{\circ} 7^{\circ} 42^{\prime} 45.0^{\prime \prime}\end{array}$ & $\begin{array}{l}\text { Queguay Formation (Middle } \\
\text { Eocene-Middle Oligocene) }\end{array}$ & C. germanica connected to tunnels & Non-fossiliferous \\
\hline $\begin{array}{l}\text { Coquimbo Creek (Uruguay) } \\
\text { S } 33^{\circ} 20^{\prime} 55.1^{\prime \prime} \text {; W } 57^{\circ} 46^{\prime} 28.7^{\prime \prime}\end{array}$ & $\begin{array}{l}\text { Mercedes Formation (Upper } \\
\text { Cretaceous) }\end{array}$ & C. germanica, $F$, gobiensis. & Molluscan shell debris \\
\hline $\begin{array}{l}\text { Sauce Solo Quarry (Uruguay) } \\
\text { S34 } 24^{\prime} 03.4^{\prime \prime} \text { W55 } 38^{\prime} 37.7^{\prime \prime}\end{array}$ & $\begin{array}{l}\text { Queguay Formation (Middle } \\
\text { Eocene-Middle Oligocene) }\end{array}$ & C. germanica, $C$. roseliii, $F$ gobiensis & Eoborus charruanus, Celtis endocarps \\
\hline $\begin{array}{l}\text { Vichadero Quarry, ANCAP (Uruguay) } \\
\text { S } 32^{\circ} 5^{\prime} 23.60^{\prime \prime} \text {; W } 57^{\circ} 50^{\prime} 3.80^{\prime \prime}\end{array}$ & $\begin{array}{l}\text { Queguay Formation (Middle } \\
\text { Eocene-Middle Oligocene) }\end{array}$ & Non-fossiliferous & Non-fossiliferous \\
\hline $\begin{array}{l}\text { Jesuita Quarry (Uruguay) } \\
\text { S32 } 05^{\prime} 52.5^{\prime \prime} \text {; W57 } 57^{\prime} 48.4^{\prime \prime}\end{array}$ & $\begin{array}{l}\text { Queguay Formation (Middle } \\
\text { Eocene-Middle Oligocene) }\end{array}$ & Non-fossiliferous & Non-fossiliferous \\
\hline $\begin{array}{l}\text { El Palmar National Park (Argentina) } \\
\text { S31 } 52^{\prime} 54.2^{\prime \prime} \text { W5 } 58^{\bullet} 12^{\prime} 16.4^{\prime \prime}\end{array}$ & $\begin{array}{l}\text { Pay Ubre Formation } \\
\text { (Cretaceous) }\end{array}$ & Rhizoliths & Non-fossiliferous \\
\hline $\begin{array}{l}\text { Colon Slope (Argentina) } \\
\text { S } 32^{\circ} 12^{\prime} 58^{\prime \prime}, \text { W } 58^{\circ} 08^{\prime} 04^{\prime \prime}\end{array}$ & $\begin{array}{l}\text { Pay Ubre Formation } \\
\text { (Cretaceous) }\end{array}$ & F. gobiensis & Non-fossiliferous \\
\hline $\begin{array}{l}\text { East of Mercedes City (Argentina) } \\
\text { S29 } 08^{\prime} 32.3^{\prime \prime} W 57^{\circ} 58^{\prime} 24.4^{\prime \prime}\end{array}$ & $\begin{array}{l}\text { Pay Ubre Formation } \\
\text { (Cretaceous) }\end{array}$ & F. gobiensis & Non-fossiliferous \\
\hline $\begin{array}{l}\text { Itá Creek, Estancia La Encarnación (Argentina) } \\
\text { S29 } 07^{\prime} 34.1^{\prime \prime} W 58^{\circ} 27^{\prime} 36.7^{\prime \prime}\end{array}$ & $\begin{array}{l}\text { Pay Ubre Formation } \\
\text { (Cretaceous) }\end{array}$ & Non-ichnofossiliferous & Non-fossiliferous \\
\hline
\end{tabular}


Pazos, 2010). According to Bossi (1966), both the Mercedes and Asencio Formations are Cretaceous, being overlain by the Fray Bentos Formation. However, Pazos et al. (1998) indicate the Asencio Formation to be Cenozoic, whereas Tófalo and Pazos (2010) indicate the Queguay, Asencio and Fray Bentos Formations to be all Cenozoic. Genise et al. (2002) and Bellosi et al. (2004) proposed the Asencio Formation to be Palaeogene, probably Early Eocene considering the occurrence of laterites and the abundance of dung-beetle trace fossils. Recently, Tófalo and Morrás (2009) and Tófalo and Pazos (2010) summarized the previous stratigraphic framework and proposed a new one based on the observations mainly made in the Paraná and
Santa Lucia Basins. The latter papers include the "Calizas del Queguay", named the Queguay Formation within the Palaeocene.

\section{Stratigraphy}

\subsection{Observations made on sections from Argentina}

Patchy outcrops of limestones are present in the NE Argentina, bordering Uruguay (Fig. 1), within Entre Ríos and Corrientes provinces. These outcrops are small (both in area and thickness), and in some cases correspond to quarries that are no longer in service
A

PN Palmar

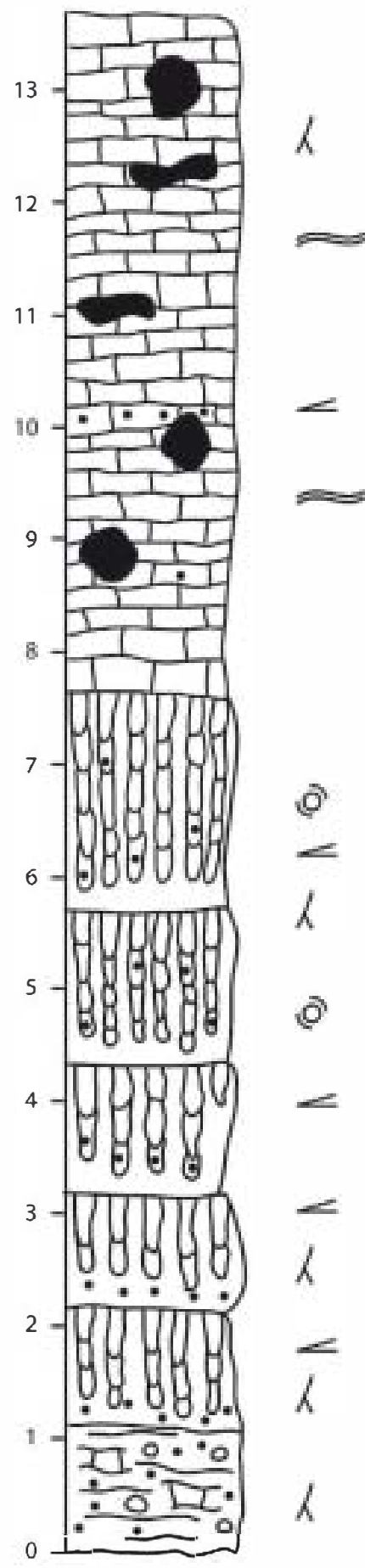

El Palmar Dam
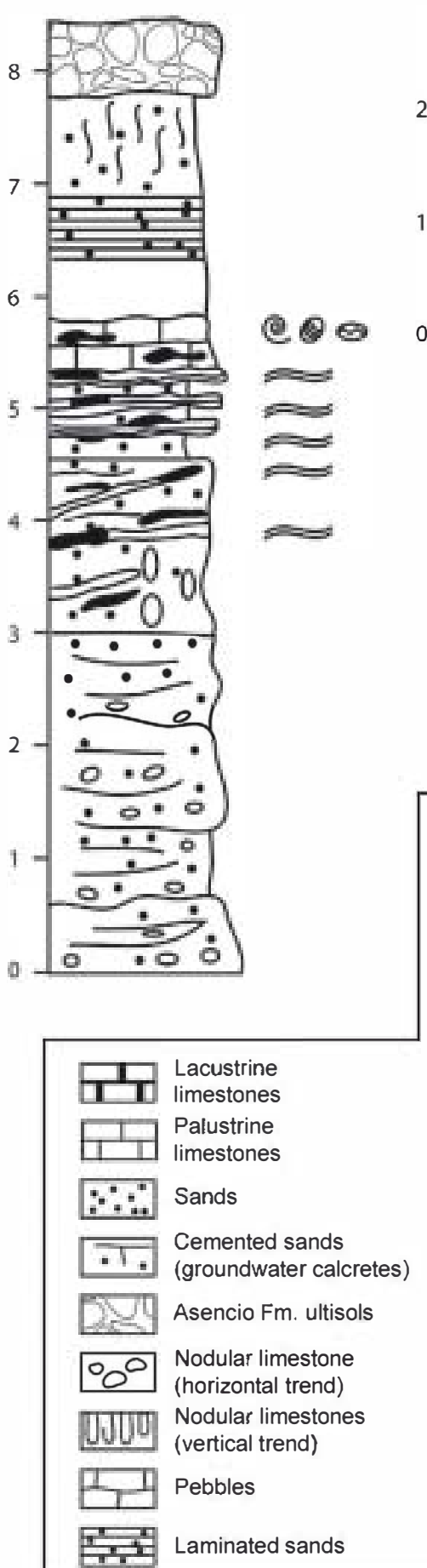

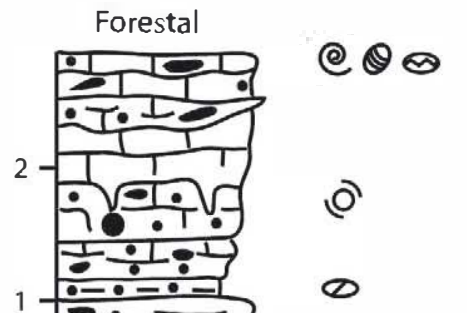

\begin{tabular}{|c|c|}
\hline$\approx$ & Laminar calcretes \\
\hline & Granular limestones \\
\hline & Chert nodules \\
\hline$\infty$ & Intraclasts \\
\hline & Clay iluviation \\
\hline e. & Gastropods \\
\hline 8 & Charophytes \\
\hline$\Theta$ & Ostracods \\
\hline$<$ & Desiccation cracks \\
\hline 久 & Rhizoliths \\
\hline ) & Mottling \\
\hline$\Pi$ & Insect traces \\
\hline 朋 & $\begin{array}{l}\text { Dessication structures } \\
\text { (vertical) }\end{array}$ \\
\hline$\Leftrightarrow$ & $\begin{array}{l}\text { Desiccation structures } \\
\text { (horizontal) }\end{array}$ \\
\hline 8 & Clasts from Asencio \\
\hline
\end{tabular}



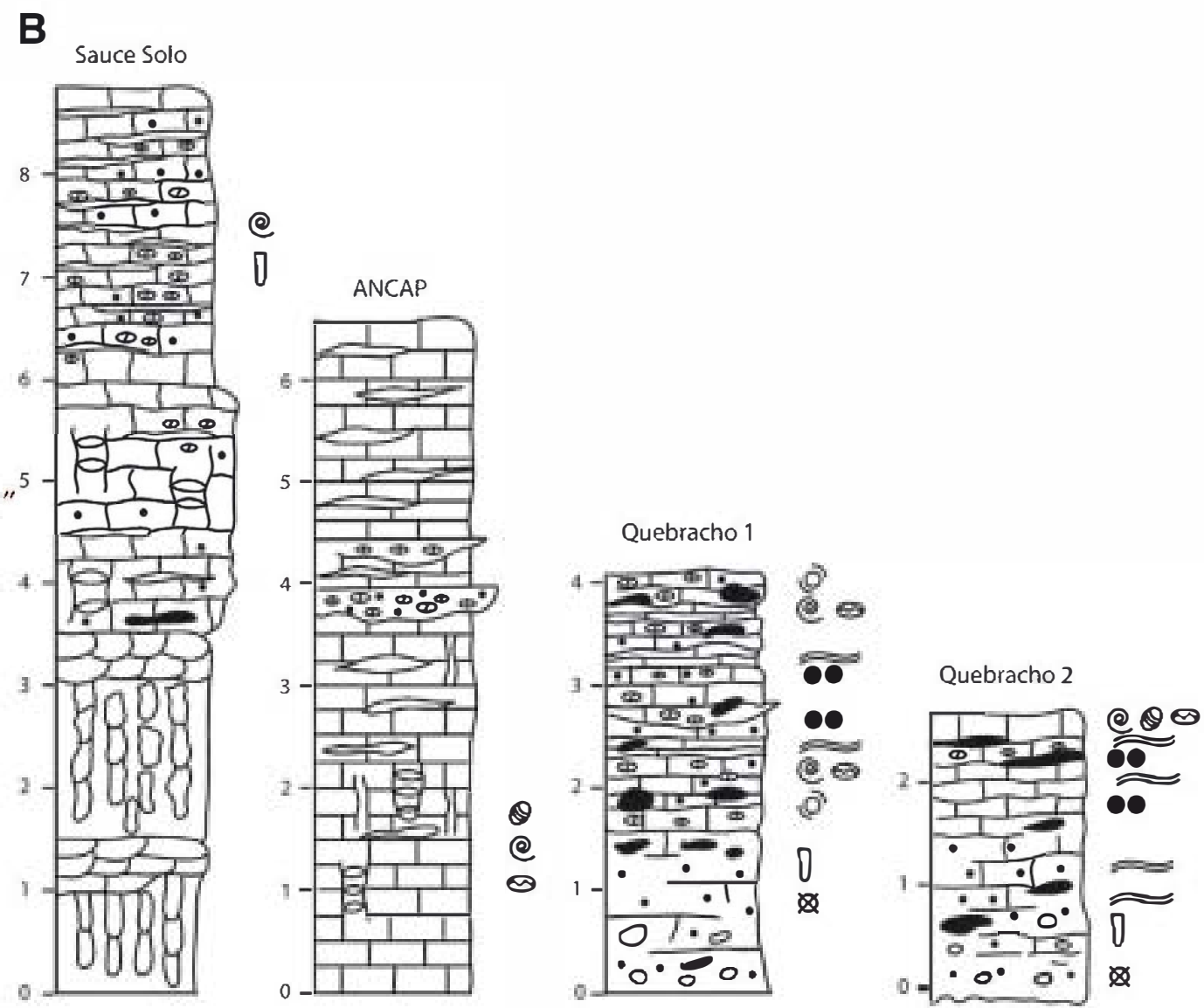

Road 26

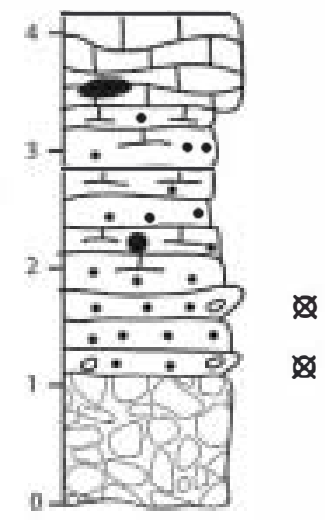

Fig. 2. Sedimentary logs. A: Sections from Mercedes Formation (Cretaceous). B: Sections from Queguay Formation (Palaeogene).

or have been covered, precluding their observation. Herbst (1980) defined the Pay Ubre Formation to include these outcrops and proposed an Upper Cretaceous age, correlating them to the "Calizas del Queguay" of Uruguay (Herbst, 1980; Herbst and Santa Cruz, 1985).

Recent fieldwork on the Pay Ubre Formation (Fig. 1, Table 2) revealed: 1) the Colón slope (Entre Ríos) has limestone-bearing trace fossils: ellipsoidal chambers compatible with Fictovichnus gobiensis; 2) in the Parque Nacional (PN) El Palmar section (Entre Ríos) (Fig. 2A) more than $10 \mathrm{~m}$ of limestones are exposed along the River Uruguay (from Prefectura to Intendencia). The only trace fossils are rhizoliths; the limestones are nodular, mottled, and are interpreted as pond deposits; 3) a bedding plane exposed beside Road 40 near the detour of Road 85 (NE of Mercedes, Corrientes) where a specimen of $F$. gobiensis was found; 4) small outcrops are present along the Itá Creek on the Estancia La Encarnación (SW of Mercedes, near Road 24, Corrientes). The limestones are also nodular, mottled, and strongly silicified. They bear some rhizoliths and F. gobiensis. The latter is the largest outcrop found in Corrientes; others are mentioned by Herbst (1980) and Herbst and Santa Cruz (1985), such as at Calera Díaz, Estancia La Emilia, and Puesto Las Ruinas. However, these were not found or were quarries that are now covered.

\subsection{Observations made on stratigraphical key sections from Uruguay}

The reference formation followed was the Asencio Formation, thus rendering three key sections: El Palmar Dam, Quebracho, and Road 26 sections (Table 2, Fig. 2). In these sections it is possible to see the contact between the Asencio Formation and its underlying or overlying units.
In the El Palmar Dam section (Fig. 2A) a fining-upwards sequence passing from coarse sandstones to fine sands and mudstones includes about $1 \mathrm{~m}$ of silicified carbonates. These carbonates occur either as thin laminae interbedded within the sands or as thicker nodules forming beds and containing gastropods, charophytes and ostracods. The base of the Asencio Formation occurs at the topmost part of the El Palmar Dam section (Fig. 3A). In the Road 26 section the Asencio Formation is overlain (Figs. $2 \mathrm{~B}$ and $3 \mathrm{~B}$ ) by several beds (in total $2.30 \mathrm{~m}$ thick) of tabular sandstones containing coarse clasts sourced from the Asencio Formation. At the top the sandstones are finer grained and have high micrite content and coarse spar cements. The sandstones pass vertically to micritic limestones with desiccation cracks and manganese staining, very similar to those that make up the ANCAP section (Fig. 2B). The two Quebracho sections show similarities with the Road 26 section. The coarse sandstones at the base also contain large clasts sourced from the Asencio Formation (Fig. 3C, D). The sandstones grade vertically to palustrine limestones with interbedded thin laminar calcretes; both are partially silicified (Fig. 2B).

\subsection{Proposal of a new stratigraphic framework}

The results of the field work in Uruguay on the stratigraphical key sections including the limestone units of the study area allow to propose the new stratigraphic framework outlined in Fig. 4. See Table 2 for fossil occurrences in the studied sections. We have studied neither the Guichón nor the Fray Bentos Formations.

The top of the Cretaceous is formed by the Mercedes Formation. In the study area it is more than $10 \mathrm{~m}$ thick and can be divided into three units $(1-3)$, the contacts of which are concordant. 

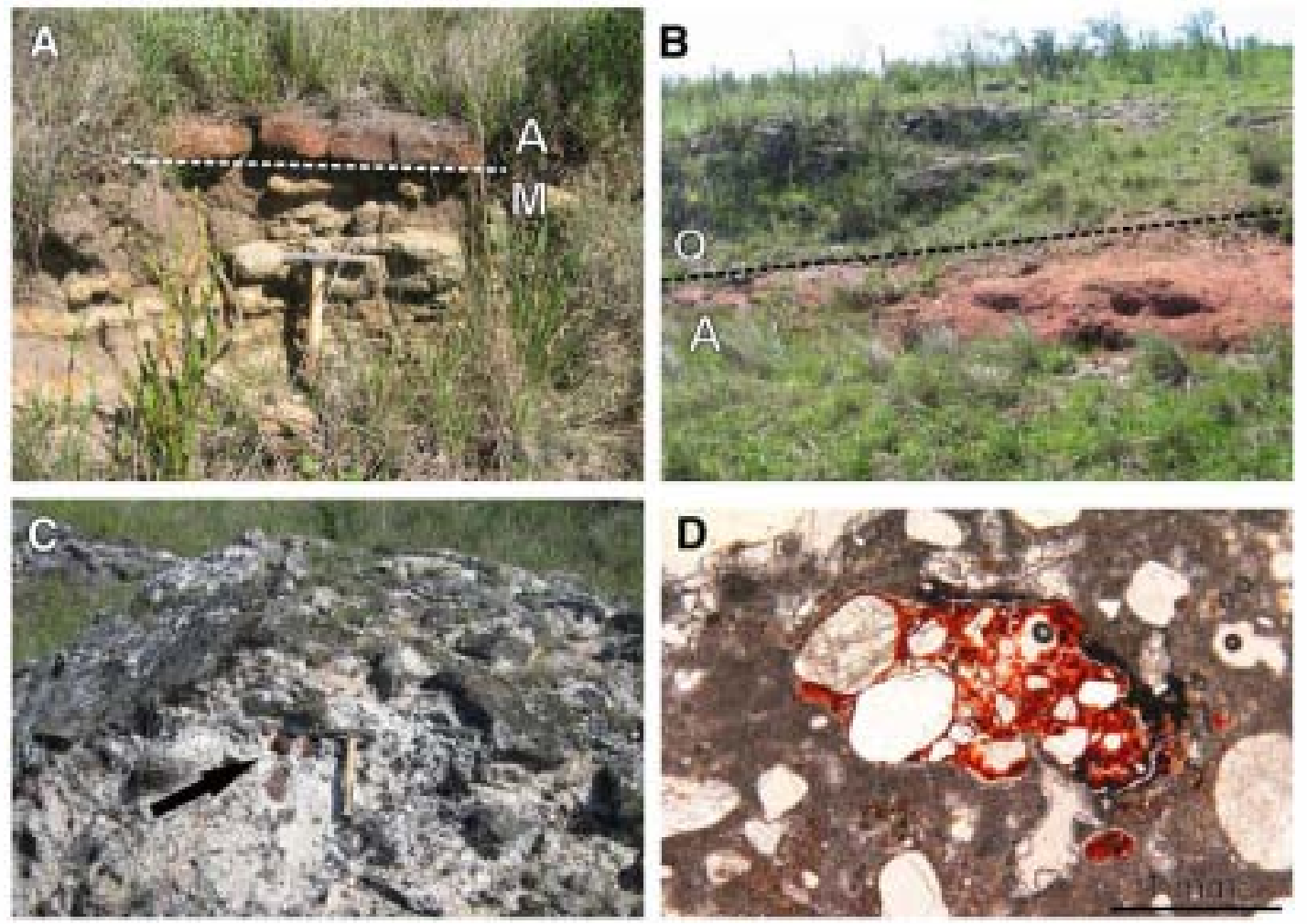

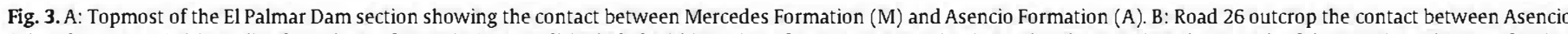

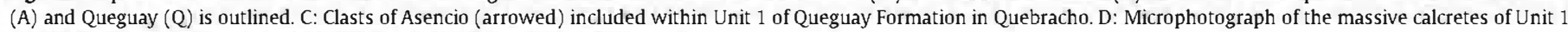
(Quebracho) showing a clast sourced from Asencio (large clast in the middle)

- Unit 1 consists of more than $5 \mathrm{~m}$ of tabular beds of coarse sands with interbedded fine gravels. Some channel-like bodies are observed and most of the sequences are fining upwards. The top of the unit includes carbonate nodules and laminae and is partially silicified.

- Unit 2 is formed by 1 to 3 m-thick, partially silicified, soft, sandy limestone beds. At the top, these beds are more indurated and include fossils of Biomphalaria gastropods, ostracods, charophytes, Celliforma germanica, Celliforma spirifer, F. gobiensis, rhizoliths, and scarce dinosaur eggshell fragments (Fig. 5). Trace fossils are more common in the La Forestal section than in the El Palmar Dam section. Both sections also provide lacustrine fossils such as charophytes, ostracods and Biomphalaria (Table 2). Silicified wood fragments also appear in this unit.

- Unit 3 is composed of $2-3 \mathrm{~m}$ of medium to fine sands of prismatic structure that show mottling. It is conformably overlain by the Asencio Formation.

The Asencio Formation, between 2 and $6 \mathrm{~m}$ thick, is herein used as a key bed within the studied area. Its age is proposed as early Eocene (Genise et al., 2002; Bellosi et al. 2004).

Apart from the Asencio Formation, the Palaeogene also includes the Queguay Formation that conformably overlies the Asencio Formation. Herein, we restricted the name Queguay Formation to the Middle Eocene-Middle Oligocene sandstones and limestones overlying the Asencio Formation. The Queguay Formation is about $10 \mathrm{~m}$ thick and is composed of two units.

- Unit 1 is less than $5 \mathrm{~m}$ thick and consists of coarse to fine sands with sparse larger clasts, some of which are sourced from the Asencio Formation (Fig. 3C). It is partially silicified and commonly contains carbonate as matrix and cements, especially at the top where it grades into Unit 2. Specimens of Celliforma are found at the base of this unit at Quebracho (Fig. 1, Table 2).
- Unit 2 is from 2 to $10 \mathrm{~m}$ thick. It consists of a lower part with sandy limestones containing partially silicified carbonate laminae, and an upper part with micritic limestones with desiccation features and less prominent silicification. The sandy limestone contains sandsized grains sourced by previously silicified limestones. Ostracods, charophytes, Celtis endocarps, Biomphalaria, Physa, and Eoborus gastropods, C germanica, C spirifer, Celliforma rosellii, Celliforma ispp, Rebuffoichnus sciuttoi (only found at Quebracho), F. gobiensis, and rhizoliths are common in this unit (Fig. 6) (Table 2).

\section{Sedimentology}

Most of the facies studied here, and especially those that contain trace fossils, are either lacustrine/palustrine carbonates or calcretes. Some of the exposures were limited and so the lateral relationships between the differentfacies were not easy to follow, however outcrops such as Sauce Solo or ANCAP permitted seeing some of these relationships. There is an important similarity between the deposits of the Cretaceous (Unit 2 of Mercedes Formation) and the Palaeogene (Unit 2 of Queguay Formation); thus, all the carbonate facies are here analysed as a whole.

\subsection{Lacustrine facies}

These limestones occur sparsely interbedded within other facies, especially with palustrine limestones. They are recognized in sections at La Forestal, the base of ANCAP, locally at Quebracho, and at El Palmar Dam (Fig. 2). They occur as beds ranging from $0.1 \mathrm{~m}$ to several metres in thickness. No lamination is visible and the beds are homogeneous. These limestones are commonly wackestones containing gastropods, charophytes, and ostracods (Fig. 7A), but no trace fossils are recognized. Charophytes and ostracods commonly preserve their initial textures, whereas gastropods are represented either by 


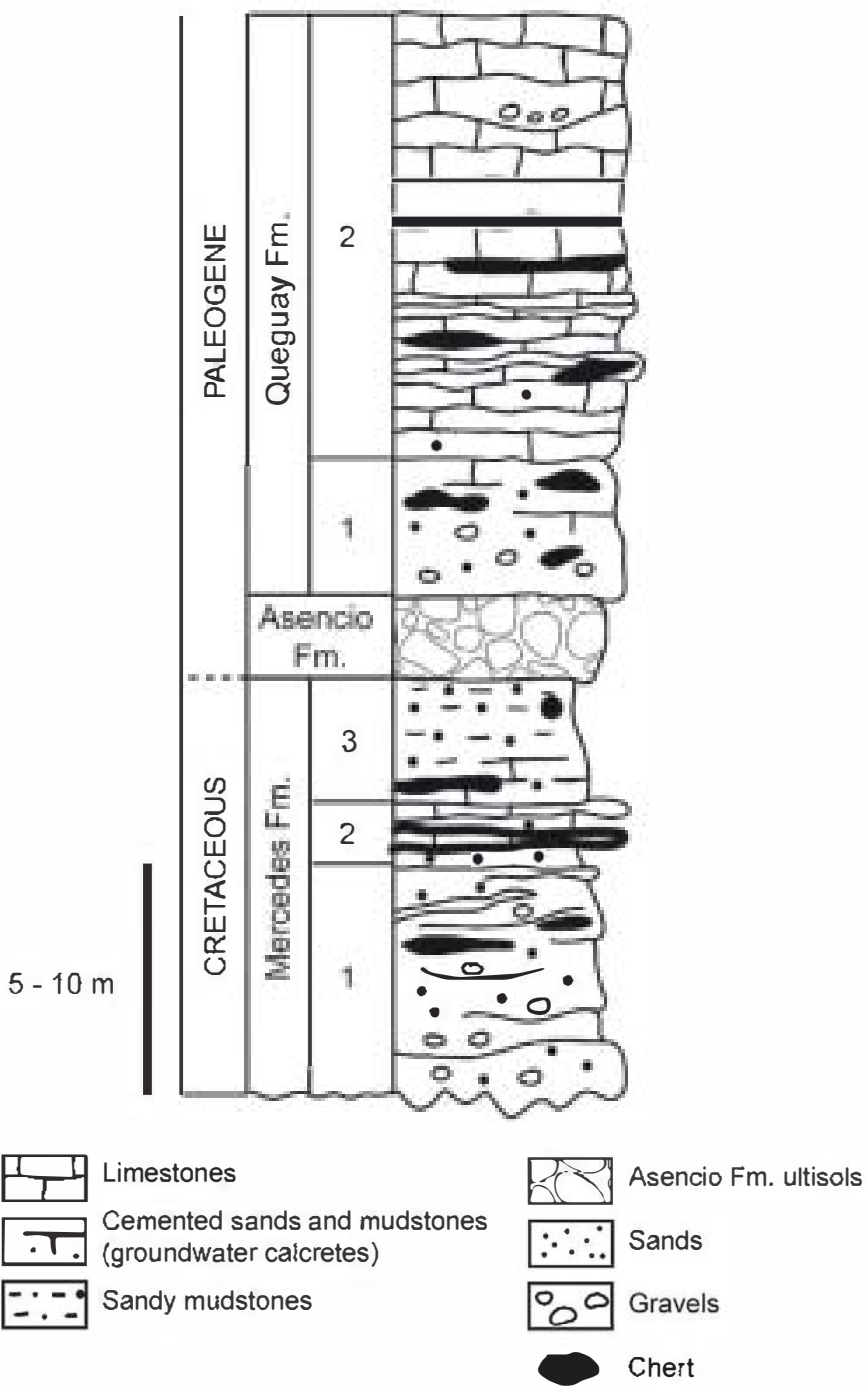

Fig. 4. Stratigraphic framework proposed for the study area.

preserved shells or moulds filled by spar calcite. Some of these limestones contain large amounts of siliciclastic grains, mostly quartz, and have few bioclasts. In some cases the quartz grains are very rounded. Lenticular calcite pseudomorphs occur after gypsum very locally in the less bioclastic limestones. Desiccation cracks and pedogenic features occur sparsely. These cracks show a first infill of coarse calcite spar, followed by fibrous or microcrystalline quartz. Rarely the cracks and some vugs contain a first infill of vadose silt.

\subsubsection{Interpretation}

This facies represents more open or perennial lacustrine deposits subjected to minor subaerial exposure. However, this interpretation does not imply deposition in a deep-water body. On the contrary, the biota and the occurrence of some desiccation features indicate the existence of very shallow, well oxygenated lakes. The thin beds in which these facies occur probably indicate short-lived lakes without significant subaerial exposure. Similar facies are very common in recent freshwater lakes such as those at Ias Tablas de Daimiel (Alonso-Zarza et al., 2006) and are seen in ancient lacustrine shallow water deposits stretching as far back as the Devonian (Dunagan and Driese, 1999). Although sometimes the massive and homogeneous appearance of these limestones seems to indicate bioturbation in shallow lake areas (Gierlowski-Kordesch, 2010), no evidence of strong bioturbation that might have totally destroyed the original fabric of the sediment is seen. The massive appearance might be due either to an increase in the sedimentation rate (Verrecchia, 2007) or to the fact that the primary micritic mud was initially precipitated as fine and homogeneous crystals later lithified (Wright et al., 1997). The preservation of many of the original morphologies of the bioclasts supports the idea of reduced bioturbation and preservation of most of the initial textural features of the sediments. The occurrence of clastic grains in some of the beds suggests that water was partially sourced from superficial currents entering the lakes.

\subsection{Palustrine facies}

These are probably the most characteristic limestones of both the Mercedes and Queguay Formations. They occur in all the studied sections and are commonly partially silicified. There are four main palustrine facies.

Desiccated mudstones. These are very common at the ANCAP quarry and in the Sauce Solo section (Fig. 2) where they form massive beds more than $1 \mathrm{~m}$ thick. The mudstones have very sparse bioclasts and variable amounts of siliciclastic grains (up to 15\%). They also show aggregates containing siliclastic grains and strongly desiccated clays. The mudstones are cut by cracks that are either empty or filled by spar cement (Fig. 7B). Single cracks are horizontal but complex and irregular networks of cracks also occur. The cracks show a complex infill with micritic fragments and quartz grains embedded either in calcite or quartz cement (Fig. 7C, D). The mudstones contain some angular or rounded micritic fragments surrounded and cut by a network of desiccation cracks. Some manganese staining lines these cracks. Trace fossils are very abundant in the desiccated mudstones of the Sauce Solo section but totally absent in the ANCAP quarry. Some thin sections from Sauce Solo preserve remains of calcified plant debris.

Nodular limestones. These occur mostly at the base of the Sauce Solo section, at the top of the La Forestal section, and in the PN El Palmar section (Argentina)(Fig. 2). Mean thickness is between 0.5 and $1 \mathrm{~m}$. They appear as horizontal but irregular limestone beds in which decimetre-scale nodules are distinguishable because they are included in a softer muddy matrix. Some nodules are horizontally elongated, whereas in others the trend is vertical. Nodular limestones are mudstones to wackestones and include ostracod, charophyte, mollusc fragments, and abundant trace fossils. Desiccation and/or root cracks are common and tend to be irregular (Fig. 8A). Some of the cracks have a first coating of iluviated clays, followed by a variety of calcite cements from fibrous-gravitational to coarse calcite spar (Fig. 8A). Some limestone fragments as well as rounded calcite crystals are also found within these cracks

Granular limestones. These occur in all the studied sections, but the best examples are seen in the Quebracho sections. They form either individual beds (up to $1 \mathrm{~m}$ thick) or are interbedded between any other facies types. These limestones are sandy packstones formed by rounded or angular micritic grains; the rounded micritic grains (ooids) are about $1 \mathrm{~mm}$ across. These micritic grains may have a nucleus either of quartz grains or fragments of re-worked limestone (Fig. 8B). They may include fossils and rarely can contain calcite pseudomorphs following gypsum. Some of the nuclei also consist of alveolar structures or fragments of chert rocks. Most of the ooids have several micritic envelopes that are very irregular, in some cases asymmetrical (thicker on the underside), or the laminae are partially recrystallized to pseudospar. The angular micritic fragments (intraclasts) are larger ( $>5 \mathrm{~mm}$ ) and show a micritic laminated coating (Fig. 8C). These intraclasts contain fragments of bioclasts. The granular limestones show a micritic matrix and include the same bioclasts as the lacustrine limestones, quartz grains, and in some cases fragments of previous chert rocks. Some of the quartz grains show a thin clay coating. Desiccation cracks are common and in some cases partially filled by 

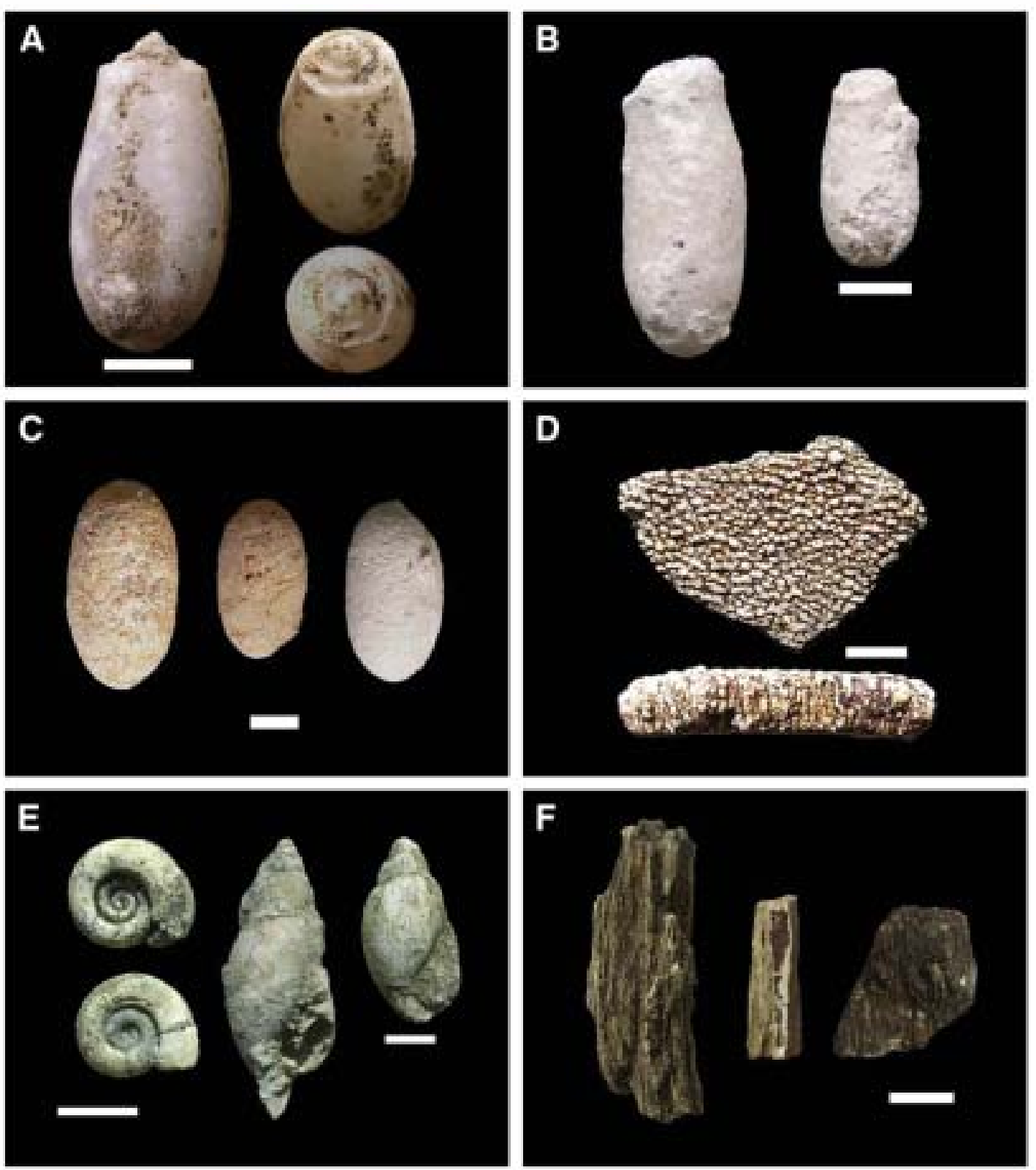

Fig. 5. Fossils from the Cretaceous unit II of Mercedes Formation. A. Celliforma spirifer, lateral view (left), oblique and opercular view (right), scale $0.5 \mathrm{~cm}$. B. C. issp., scale $0.5 \mathrm{~cm}$. C. Fictovichnus gobiensis, scale $0.5 \mathrm{~cm}$. D. Dinosaur eggshell fragment, scale $0.5 \mathrm{~cm}$. E. Freshwater gastropods, Biomphaiaria (left) and Phys (right), scale $0.5 \mathrm{~cm}$. F. Silicified wood fragments, scale $1 \mathrm{~cm}$.

vadose gravitational cement. Alveolar septal structures (Fig. 8D) are very common, cutting the entire structure of the rock; they show a network of rounded pores surrounded by laminated micrite. Root sections and calcified cells are found in association with the alveolar structures as well as finer grained $(<1 \mathrm{~mm})$, coated micritic grains. Granular limestones seem to be the more favourable facies for trace fossils; for example, the greatest variety of trace fossils is found in the granular limestones of the Quebracho locality (Table 2).

Gravel-sheets have only been recognized in the ANCAP section. The thickest is $90 \mathrm{~cm}$ and shows an erosive base on the underlying limestones (Fig. 8E). Its lateral continuity is not easy to observe, although it is possible to follow it for about $100 \mathrm{~m}$. It is composed of clasts up to $10 \mathrm{~cm}$ across, most of which are micritic and sourced from the underlying desiccated limestones (Fig. 8F), although there are other clasts composed of chert. The matrix is sandy. No trace fossils are recognized.

\subsubsection{Interpretation}

The limestones described here preserve very well their primary lacustrine features, such as micrite and bioclasts, as well as the features that resulted from their subaerial exposure leading to their pedogenic and early diagenetic modification (desiccation cracks, rhizoliths, trace fossils, etc.). Thus, these limestones can be considered typical palustrine limestones according to the definition of Freytet (1984). These facies illustrate the different degree of modification of the primary lacustrine mud with bioclasts. The less developed palustrine limestones (shorter subaerial exposure) are desiccated micrites in which the original lacustrine wackestone is only modified by desiccation cracks. More prolonged exposure led to the formation of the nodular limestones in which desiccation and/or root activity led to the individualization of nodules via a network of cracks. These cracks were later filled by vadose and phreatic cements (Freytet, 1973). The formation of these limestones may occur in single or multiple events (Alonso-Zarza and Wright, 

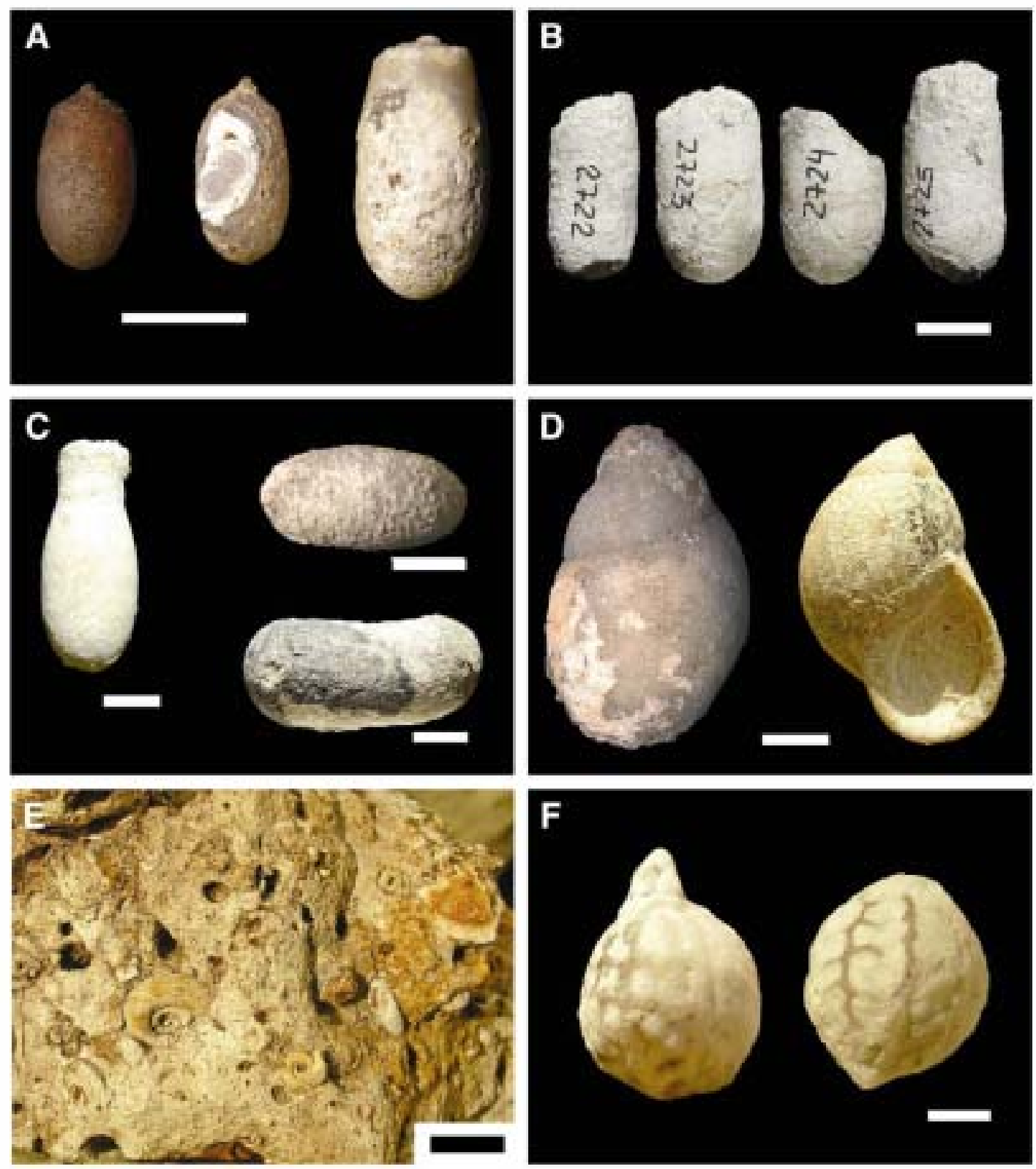

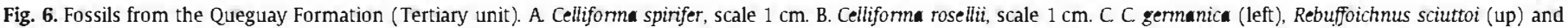
Fictovichnus gobiensis (down), scale $0,5 \mathrm{~cm}$. D. Eoborus charruanus, scale $1 \mathrm{~cm}$. E. Field photograph with Biomphaiaria, scale $1 \mathrm{~cm}$. F. Celitis endocaips, scale $2 \mathrm{~mm}$.

2010a), but thick nodular beds such as those in the Sauce Solo section probably indicate multiple sedimentation-exposure events.

The more complex palustrine facies - the granular limestones - have in some cases been interpreted as resulting from prolonged groundwater effects, such as Martinez et al. (1997) Veroslavsky et al. (1997). However, more recent papers (Tófalo and Morrás, 2009; Tófalo and Pazos, 2010) also consider them to be palustrine features. In fact, granular limestones are one of the most typical palustrine facies (Huerta and Amnenteros, 2005). They are also known as peloidal, coated grain and/or intraclastic limestones (Alonso-Zarza and Wright, 2010a). Their formation is the result of the repeated wetting and drying of carbonate mud, where root penetration contributes to this mud's intense fragmentation (Amenteros et al., 1997). Iater reworking, organic activity, intemal sedimentation, and vadose and groundwater cementation produced a complex limestone fabric (Alonso-Zarza et al., 1992). Granular limestones are thought to be the most developed palustrine fabrics and to reflect the most intense modification processing of the initial mud to form a syngenetic grainstone (Mazzullo and Birdwell, 1989). However, these modifications occur not long after sedimentation.

The sparse occurrence of gravel sheets confirms the fragmentation of the mud as syngenetic; then these fragments are incorporated into subsequent sedimentary events. Gravel-sheets and channels filled by carbonate fragments, as the one present in the ANCAP section, are commonly recognized in palustrine sequences. These deposits probably indicate longer periods of desiccation (Alonso-Zarza et al., 2006) of the lacustrine sediments and the reworking of the clasts via the incision of fluvial channels that eroded the brecciated palustrine deposits. These channels also carried non-carbonate fragments, which indicate their source to have been outside the carbonate lake system. The Bonneville Basin of North America also shows gravel and sand channels developed during regressive phases when the corresponding lake levels were low (Oviatt et al., 2003). 

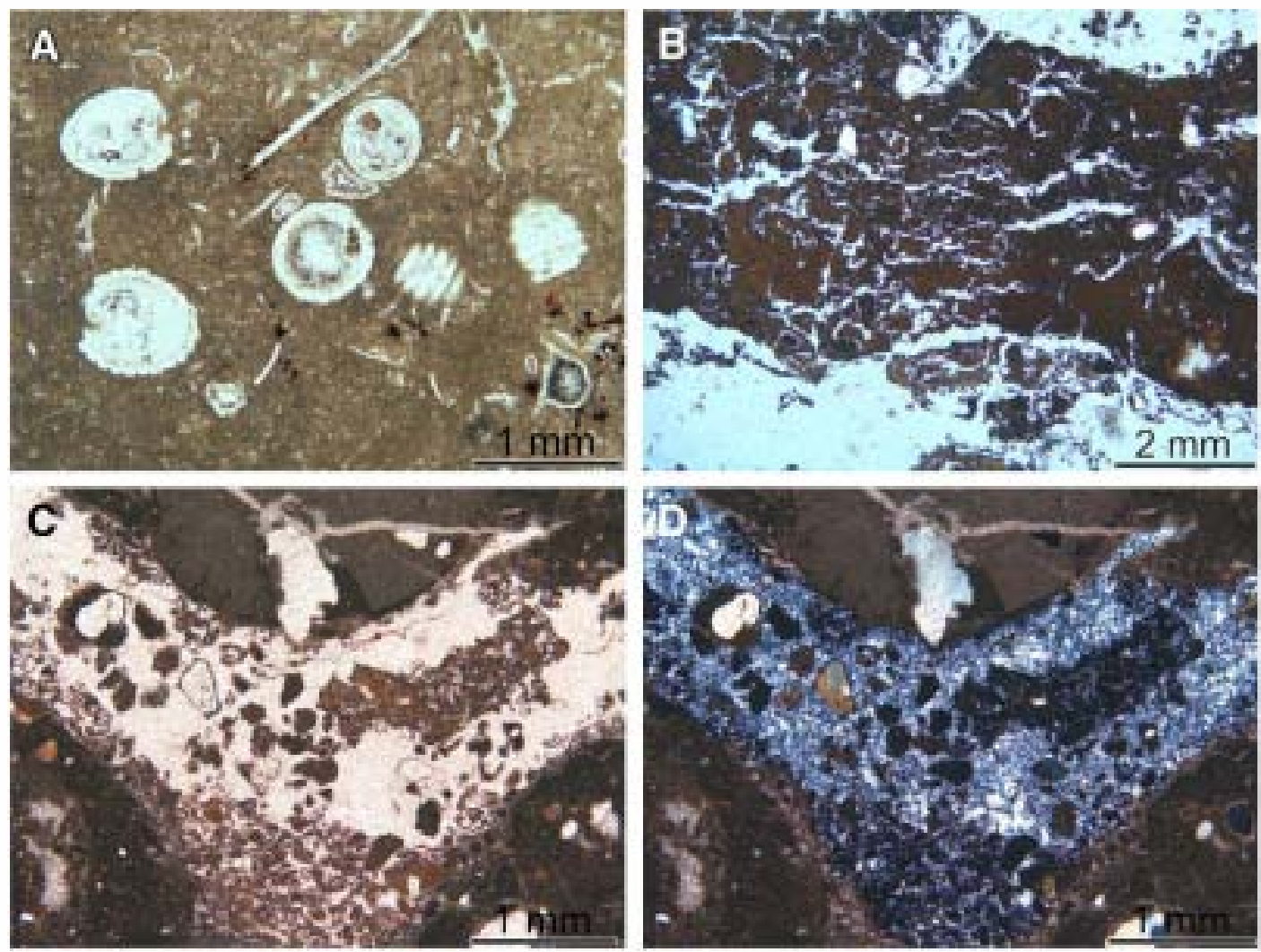

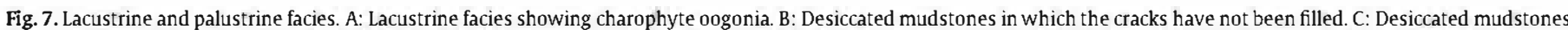
the cracks show a complex infill of micritic fragments, opal and quartz cements (plane-polarized light). D: Same as C with cross-polarized light.

\subsection{Calcretes}

Two main types of calcretes have been identified in the study area: massive and laminar calcretes.

Massive calcretes vary from sandy limestones to sands that are very rich in carbonate matrix and cements. They commonly occur in the sandstone beds of the Mercedes (Unit 2) and Queguay Formations (Unit 1) (Fig. 4). The sand grains are of quartz, feldspar, and rock fragments including limestone silicified grains. The grains are rounded to subangular and are commonly associated with clay cutans. Both the clay cutans and the grains are corroded by a mosaic of calcite crystals (Fig. 9A, B). The matrix is micritic but shows recrystallization to pseudospar (Fig. 9A, B). All these characters are indicative of an alpha microfabric (Wright and Tucker, 1991). Prismatic calcite cements occur on the clay cutans, or directly on the grains when silicified, as well as in cracks in the micrite matrix. However, the fabric of the calcrete is preserved after silicification (Fig. 9C, D). In the Road 26 and Quebracho sections these calcretes (initially sandstones) include up to $10 \%$ of clasts sourced from the underlying Asencio Formation; these are rounded to angular and of very diverse sizes $(\mathrm{mm}$ to $\mathrm{cm})$. The presence of these clasts, from Asencio, causes the staining of the calcretes, giving an orange colour to these rocks. Trace fossils are not common in this facies, except for some Celliforma in the Quebracho sections.

Laminar calcretes occur as centimetre-thick layers either within sandy layers, such as in the El Palmar Dam section (Fig. 9E), or within palustrine limestones, such as in the Quebracho section (Fig. 9F) or the La Forestal sections. At the El Palmar Dam the laminar calcretes occur within a $0.7 \mathrm{~m}$-thick bed of well-bedded medium-grained sandstones with clay cutans. The laminar calcretes are silicified and show a network of calcified/silicified root mats with very good preservation of the alveolar structures (Fig. 9E, F). Root traces and filaments can be recognized. These biogenic features are typical of beta microfabrics (Wright and Tucker, 1991). Patches of coarse equant calcite mosaic are distributed irregularly and corrode the quartz grains. When the laminar calcrete layers occur within palustrine deposits, such as in the La Forestal sections and particularly in the Quebracho sections, they are more difficult to recognize. Those that are silicified are more easily seen. These thin calcrete layers show alveolar septal structures and include fine rounded and coated micritic grains (ooids); they disrupt the palustrine features of the limestones on which they developed.

\subsubsection{Interpretation}

The calcretes described here are indicative of different pedogenic and diagenetic processes. The lack of biogenic features in the massive calcretes, the corrosion features and the calcite cements indicate intense cementation and replacement of the primary clastic sediments by carbonate, indicating their groundwater origin (Jutras et al., 2007; Alonso-Zarza and Wright, 2010b). Despite the intense precipitation of calcium carbonate, some of the quartz grains preserve their initially rounded morphology and even their earlier pedogenic clay cutans, indicating the partial preservation of the original sediment, such as the clasts sourced from the Asencio Formation. The fact that in the El Palmar Dam or Quebracho sections the groundwater effects are more prominent in the siliciclastic deposits, and less so in the lacustrine is an indication of a very shallow water table that modified the sediments when it rose to form a shallow lake. It is important to note that the groundwater calcretes described here do not correspond to massive and thick phreatic hardpans, such as those described by Jutras et al. (2007) for the Mississippian of Canada. Rather, they are here restricted to the more porous levels and tend to preserve their initial textures. This indicates that modification occurred within the same sedimentary unit and not at a later time. 

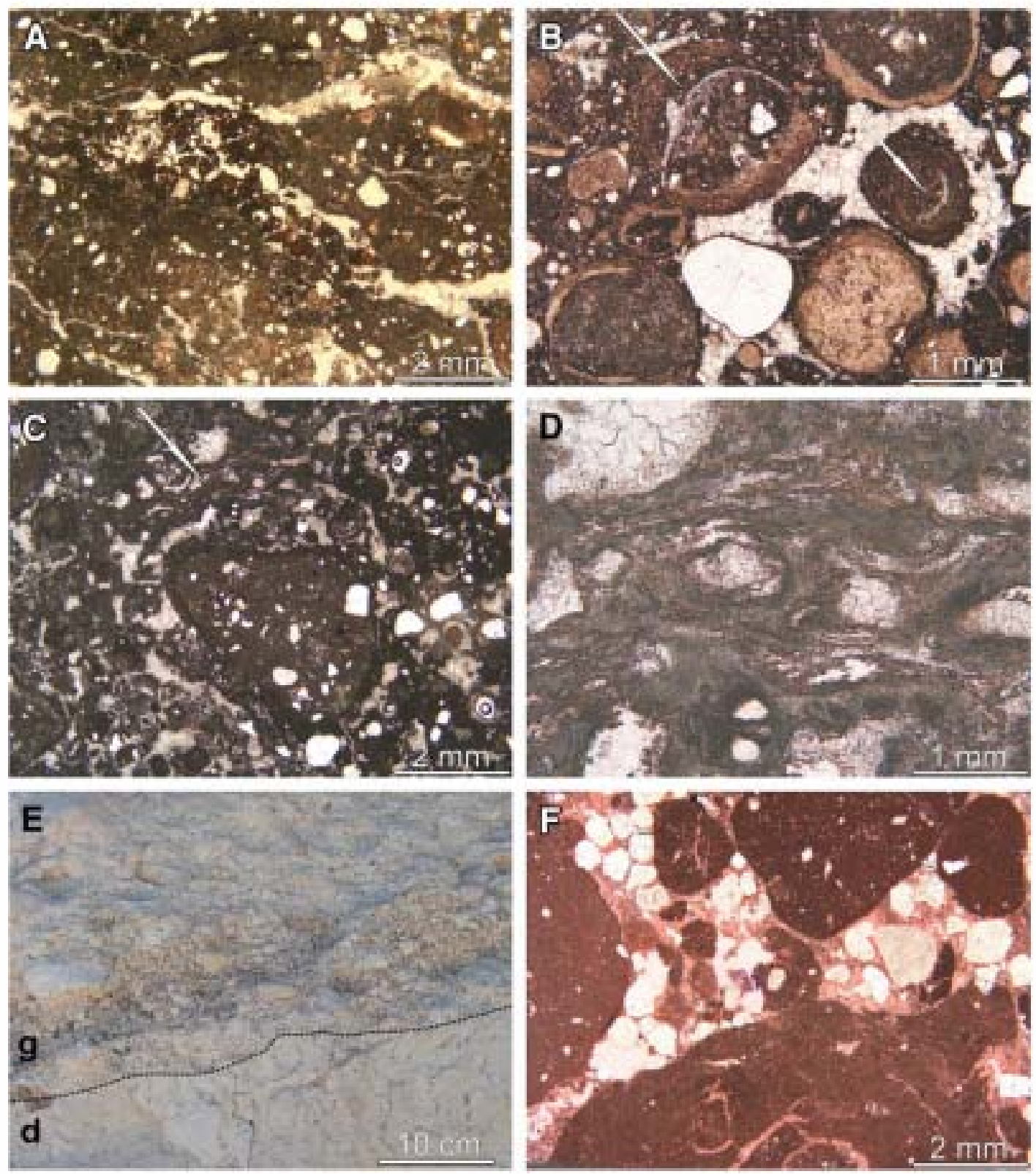

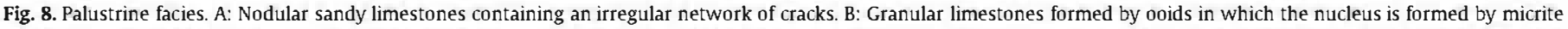

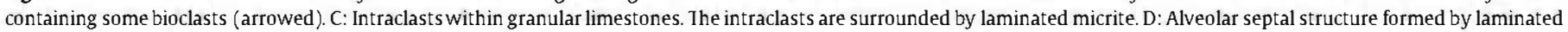

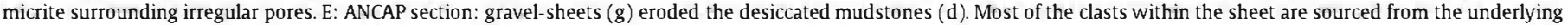
mudstones. F: Microphotograph of a stained thin section from the gravel-sheet of E. Most of the clasts are micritic.

Laminar calcretes correspond to calcified root mats in which the alveolar septal structures represent the calcification of fine root tubules and associated fungal filaments (Wright et al., 1988; Wright, 1989). The role of roots in the formation of these calcretes is so important that in some cases they are named rootcretes (Jones, 1992), rhizogenic calcretes (Wright et al., 1995), root calcretes (Alonso-Zarza and Jones, 2007) or laminar calcretes formed by calcification of mostly horizontal root systems. Root mats develop in different types of sediment, such as the sandstones of the El Palmar Dam section, or the palustrine limestones of the Quebracho section. Thin calcified root mats such as those described here may also develop by phreatophytes in relation to a very shallow, perched groundwater table (Semeniuk and Meagher, 1981). The fact that the laminar calcretes occur either in the transition between the siliclastic and palustrine deposits or disrupting the palustrine deposits may indicate that plants were able to extract water from a progressively rising or descending water table (in the El Palmar Dam and Quebracho sections). Roots would disrupt the previous palustrine facies during a fall in the groundwater table.

\section{Silicification}

All the studied facies are partially replaced and cemented by silica. Silica appears as discontinuous centimetre-scale nodules and follows some of the bedding of the limestones, especially the laminar calcretes. Some of the trace fossils are also silicified. Silicification is either of quartz or opal (Fig. 10A, B); in most cases the primary texture is preserved (Fig. 10C, D, E).

Opal is mostly massive and isotropic and replaces the micritic components either with matrix or grains (ooids, intraclasts). Opal is more abundant in the palustrine (Fig. 10A, B) and lacustrine (Fig. 10C, D) limestones than in the calcretes. The opal neatly preserves the primary texture of the rock. In some places, opal replaces the shells of some 

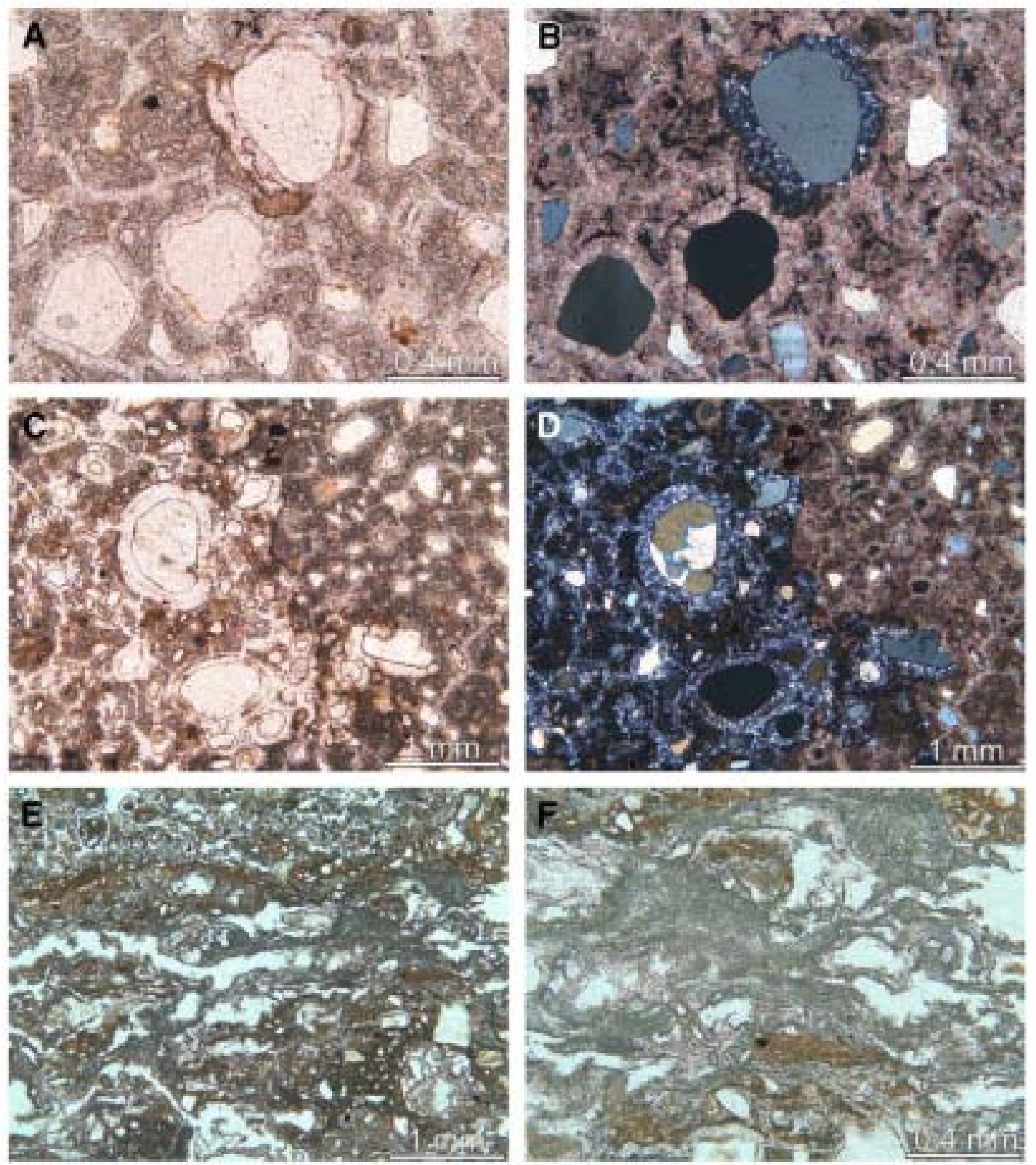

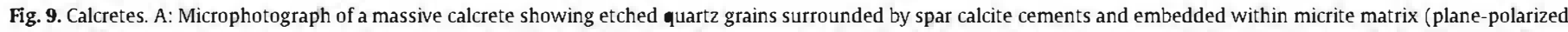

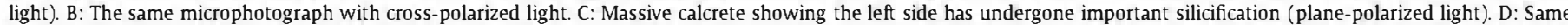

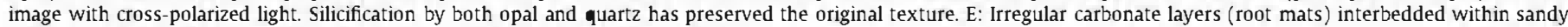
mudstones. F: Detailed view of root mats interlayered within palustrine deposits.

gastropods (Fig. 10E). More rarely it occurs as the first cementation phase pre-dating quartz cementation (Fig. 10F). In this situation the opal cement is mostly of fibrous opal (lussatite). In calcretes, opal appears to be replacing the micrite matrix or the micritic filaments of the alveolar structures.

Quartz appears as mosaics of equigranular crystals or as chalcedony (fibrous-radial textures) (Fig. 10E). It occurs either as cement or replacing previous carbonate textures. The cements fill different types of porosity (vug, desiccation/brecciation, intragranular and intergranular). In laminar calcretes quartz fills the porosity within the alveolar structures. Quartz commonly replaces the shells of bioclasts such as charophytes (Fig. 10C, D) and gastropods. In groundwater calcretes, the prior calcite cements (Fig. 9B,C,D) and some recrystallized micrite matrix are commonly replaced by quartz. This indicates that most of the silicification processes occurred after groundwater calcite cementation and/or recrystallization.
The study of the silicified limestones provides the following main results: 1) silicification neatly preserves the primary texture of all the studied deposits; 2 ) the replacement process is texturally controlled since fine crystalline carbonates are replaced by opal whereas coarser calcite textures are replaced by quartz; 3) quartz cementation generally postdates both opal cementation and calcite spar cementation, and 4) silicification is in most cases the last diagenetic process affecting these limestones, but it is still an early process as some of the massive calcretes include fragments of previously silicified limestones.

These results indicate that silicification very probably occurred in a groundwater environment since 1) quartz replaces some calcite phreatic cements, 2) there is no evidence of vadose cementation, and 3) groundwater silicification tends to preserve original textures (Bustillo, 2010). This is in agreement with the results obtained by Tófalo and Pazos (2010) within the same sedimentary deposits. Silicification was very probably produced by $\mathrm{pH}$ changes due to the 

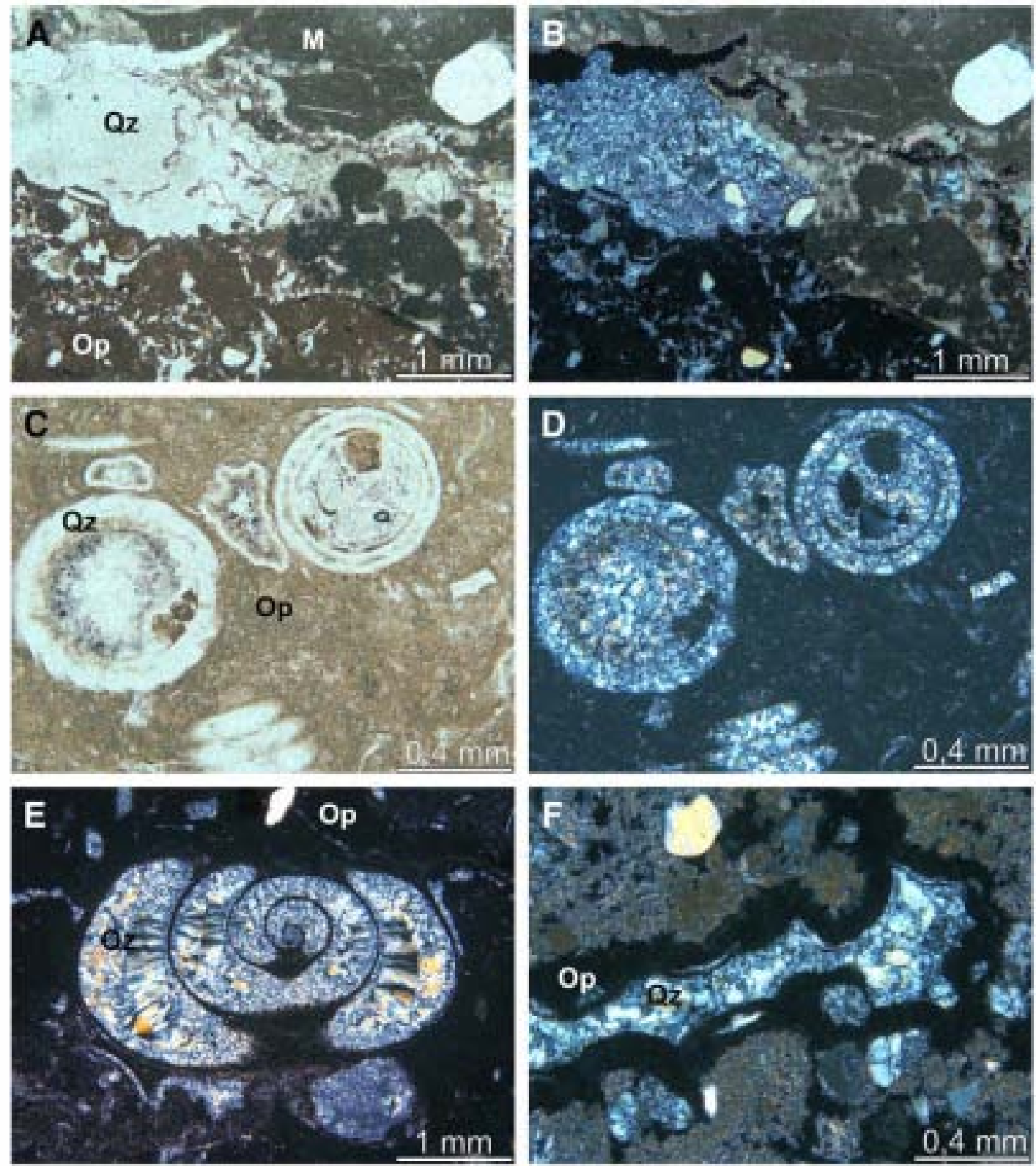

Fig. 10. Silicification. A: Partially-silicified palustrine bed. The image shows both the replacement of the initial micrite by opal (Op) in the lower part of the picture and the cementation of the cracks mostly with quartz (Qz) cements. The upper part is not silicified. The initial texture is neatly preserved after silicification (plane-polarized light). B: Same image with cross-polarized light. C: Totally silicified lacustrine limestone preserving the initial texture. Opal mostly replaces the micrite matrix, whereas auartz replaces the bioclasts and fills their porosity (plane-polarized light). D: Same image with cross-polarized light. E: Palustrine limestone in which the matrix and bioclasts shells are replaced by opal. Quartz fills the porosity within the bioclasts (cross-polarized light). F: Image showing the initial cementation of a crack by opal and later quartz cement (cross-polarized light).

flow of freshwater within the carbonate sediments, and silica was mostly sourced from the weathering of the silicate minerals (Summerfield, 1983; Nash and Ullyoot, 2007) of both the underlying volcanic rocks or from the grains or matrix of the different sandstones deposits within the basins. The presence of both opal and quartz is more an indication of the original texture of the silicified components than of changes in water geochemistry or ageing processes. Textural and compositional silica textures reflecting the primary composition and texture of the sediments are common and also are described, for example, for the Miocene of the Madrid Basin (Bustillo and Alonso-Zarza, 2007).

\section{Discussion}

The two limestone units identified in this paper (Unit 2 from the Mercedes Formation and Unit 2 from the Queguay Formation) reflect two stages of deposition of terrestrial carbonates over the Uruguayan shield. Both units are separated by the Asencio Formation and by the topmost unit of the Mercedes Formation (Unit 3). Within the basin, the infill of accommodation space by Unit 1, mostly siliciclastic sediments from the Mercedes Formation, is accounted for by the progressive rise in the water table, leading to either the formation of groundwater calcretes or the emergence of the lal se to form palustrine or lacustrine carbonates. In addition, roots colonized both the sand and lime mud deposits to form laminar calcretes. A similar situation is envisaged for Unit 2 of the Queguay Formation, but here the palus rine limestones are thicker and indicate a more persistent palustrine environment. Thus, the two units were deposited in a very flat landscape, evolving laterally and vertically from distal fan/fluvial environments to lacus rine ones. The features of the lacustrine/palustrine limestones indicate that these areas were also very flat and their water bodies very shallow. 


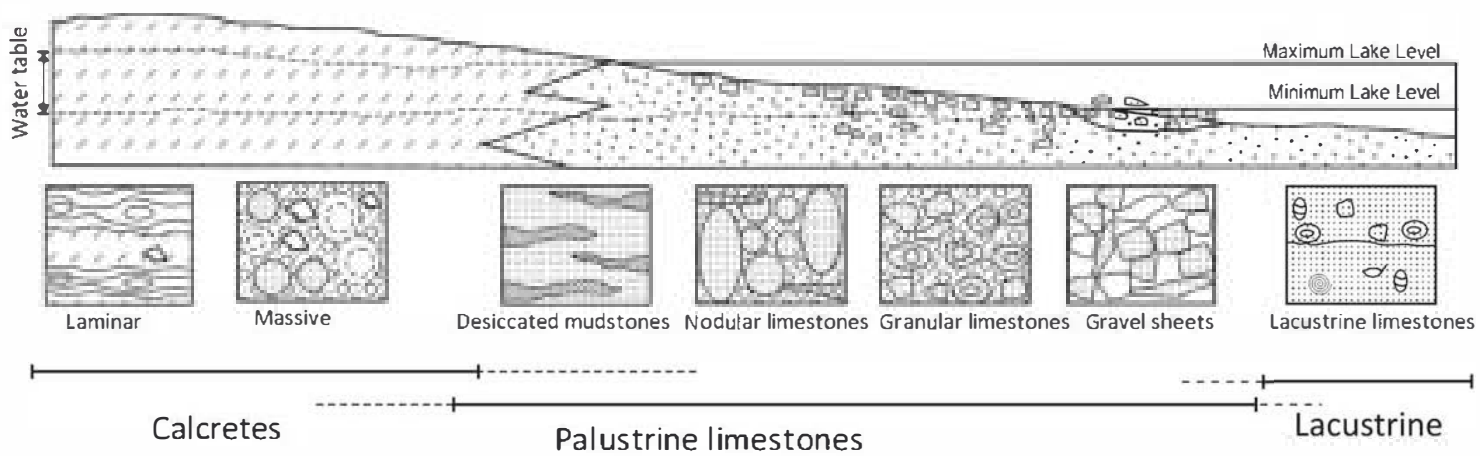

GASTROPODS

CHAROPHYTES

OSTRACODS

TALAFRUITS

EGG FRAGMENTS

INSECT TRACES

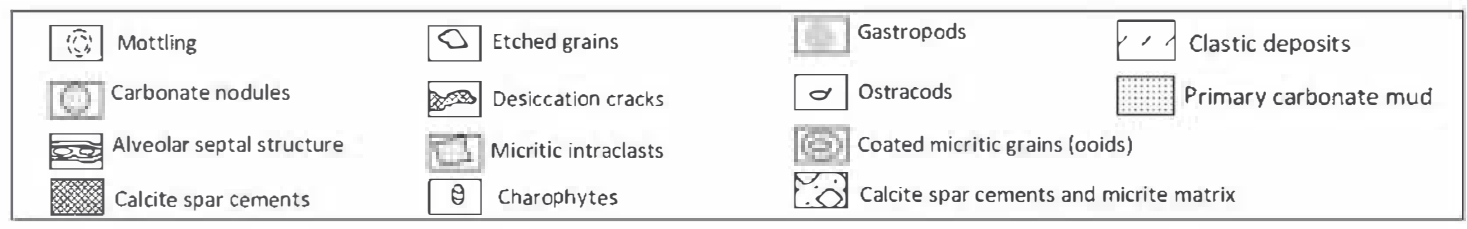

Fig. 11. Idealized sketch of the distribution of the carbonate facies, showing their fossil content. Based partially on field observations.

The modern analogues for the environments in which palustrine limestones form are wetlands (Wright and Platt, 1995; Reuter et al., 2009). Some well known ancient and recent wetlands developed near the sea (Platt and Wright, 1992; MacNeil and Jones, 2006). However, in the study case there is no sign of any marine influence. Wetlands are sourced either from surface or ground waters. Recent, non-marineinfluenced wetlands such as Las Tablas de Daimiel (Alonso-Zarza et al., 2006) may have both types of recharge. Knowledge of water table oscillations are crucial when trying to determine the complex interfingering between sedimentary and pedogenic facies and in understanding environments over space and time. Changes from pedogenic to groundwater calcretes and later on to lacustrine/ palustrine limestones have been commonly described (Alonso-Zarza, 2003), for example in the Miocene Duero Basin (Huerta and Armenteros, 2005; Armenteros and Huerta, 2006) or in the Hagul Formation of Egypt (Khalaf and Gaber, 2008). In the limestones studied in this paper, the changes are different because of the lack of typical pedogenic calcrete profiles such as those described by Esteban and Klappa (1983). In the present study, the groundwater calcretes developed very early on the sand deposits, while laminar calcretes formed later after the water level dropped. In these conditions they formed either on the sands or on the palustrine limestones soon after deposition. This is different to other situations described in the literature where the initial calcrete development is pedogenic, followed by increasing groundwater calcretisation over time, e.g., the Quaternary calcretes of SE Spain (Stokes et al., 2007) or the Pliocene of Egypt (Khalaf and Gaber, 2008).

Palustrine deposits are common in areas of arid to sub-humid climate (Platt and Wright, 1992). In the present work, the absence of evaporites and organic-rich deposits indicates that semi-arid climates prevailed during the deposition of the two limestone units. The formation of groundwater calcretes is also favoured under semi-arid conditions (Alonso-Zarza and Wright, 2010b). In addition, there is no formation of dolomite which would indicate more saline lakes if present (Deocampo, 2010). In short, the two limestone units studied in this paper formed under semi-arid climates in very shallow freshwater lakes. The different palustrine facies - desiccated mudstones to granular limestones - indicate different degrees of exposure in relation to the position of the lake shoreline (Fig. 11). This causes variations in the degree of pedogenic modification of the lake mud, giving rise to the more modified granular limestones, the less modified desiccated mudstones, and the non-modified lacustrine limestones.

Insect trace fossils provide additional palaeoenvironmental information. Insects nest mostly in well aerated soils to avoid excessive moisture that might induce the decay of organic provisions laid down in their breeding cells (Genise, 1999; Genise et al., 2004). Associations of fossil bee cells and wasp cocoons (e.g., C. spirifer, C. rosellii, C. germanica, R. sciuttoi and others) (the Celliforma ichnofacies) in carbonate-rich palaeosols (Genise et al., 2010) are good indicators of the moisture conditions of soils. Micritic limestones with bioclasts lacking desiccation structures are interpreted herein as reflecting lacustrine palaeoenvironments, and accordingly bearing no terrestrial insect trace fossils (Fig. 11). In turn, limestones from the Sauce Solo, La Forestal and the lower part of the Quebracho sections, interpreted as palustrine deposits, show a great diversity of trace fossils. The different palustrine facies show changes in diversity that may correspond to variations in the lake shoreline and the moisture content of the substrate, from subaquatic (Mermia ichnofacies), excessive damp or frequently waterlogged (Scoyenia ichnofacies), to subaerial or well aerated conditions (Celliforma ichnofacies) (Genise et al., 2010). The 
granular limestones would therefore be very favourable towards insect nesting sites while some of the desiccated limestones would be less favourable (see Fig. 11). Insect trace fossils would be also present in calcretes formed in semiarid environments (Genise et al., 2010).

The two limestones units defined herein, reflecting semi-arid climates are separated by the Asencio Formation, which was deposited during a period of increased precipitation probably by the Early Eocene Climatic Optimum, as proposed earlier by Genise et al. (2002) and Bellosi et al. (2004).

\section{Conclusions}

The main findings of our paper can be summarized as follows:

1. The carbonates that form part of the infill of the Cretaceous and Palaeogene of the Chaco-Paranense and Santa Lucía Basins constitute two different stratigraphic units. The lower one is located towards the top (Unit2) of the Mercedes Formation. Itis Cretaceous in age and is overlain by Unit 3 and the Asencio Formation, which is Early Eocene in age. The upper carbonate unit is located above siliclastic deposits that conformably overlie the Asencio Formation. These carbonates constitute Unit 2 of the Queguay Formation, and its age is interpreted to be Middle Eocene-Middle Oligocene, because it is overlain by the late Oligocene Fray Bentos Formation.

2. The two limestones units were deposited in shallow lake complexes with a well defined palustrine area. The palustrine environment graded laterally to fluvial/alluvial areas characterized by important calcrete development. The calcretes are either massive or laminar. The massive calcretes mostly consist of sandy carbonates well cemented by carbonate and/or silica, formed under shallow groundwater conditions. The laminar calcretes are associated with all other sedimentary facies and represent thin calcified root mats. The palustrine limestone includes desiccated mudstones, nodular limestones, granular limestones and gravel sheets. The reworking of the mud to form the gravel-sheets is proof that not even the granular limestones should be interpreted as the result of prolonged diagenetic effects. On the contrary, these limestones indicate that several periods of subaerial exposure occurred soon after the deposition of the limemud, and only affected the previously deposited sediments. The lacustrine deposits represent more perennial subaqueous lake deposits. The overall limestones facies (calcretes, palustrine and lacustrine) and their lateral distribution likely represent wetland fluvio-lacustrine environments that developed in semi-arid to subhumid climates.

3. The distribution of trace fossils shows clear facies/environmental control. The more permanent lacustrine environments lack any insect traces, whereas the laminar calcretes of palustrine environments exhibit them, with the exception of the gravel sheets. Recorded trace fossils for both limestone units are: $C$. rosellii, C. gernanica, C. spirifer, C ispp, F. gobiensis, and rhizoliths. $R$ sciuttoi was only recorded for the Paleogene unit at Quebracho. Recorded body fossils from both units are: Physa and Biomphalaria gastropods and characean oogonia. Whereas, the Cretaceous unit bears dinosaur egg shells, and the Paleogene one at Quebracho, Celtis endocarps and the gastropod Eoborus. The presence of the latter at Sauce Solo suggests a Palaeogene age for this locality.

4. Both units of limestones and their trace fossil associations (representative of the Celliforma ichnofacies) record two periods of semi-arid climate, separated by one of increased precipitation during the Early Eocene Climatic Optimum represented by the Asencio Formation and its trace fossil association (representative of the Coprinisphaera ichnofacies).

5. The limestones are partially silicified, either by opal or quartz. Silicification was produced in a groundwater meteoric environment and preserved the texture of the limestone.
In short, the study carried on the Cretaceous and Paleogene limestones of Uruguay has allowed obtaining a clear stratigraphic and sedimentological framework for these limestones in which race fossils have been included. Our study confirms the preference of the Celliforna ichnofacies for semi-arid environments such as calcretes or palustrine carbonates.

\section{Acknowledgements}

This paper is a contribution to Projects CGL-2008-05584-C02-02 of the MCINN (Spain), UCM-910404 of the UCM-CAM-BSCH (Spain), FONCYГ-PICT 07/1972 of the ANPCYГ (Argentina), and DINACYГ FCE 2005/010 and ANII FCE 2007/44 from Uruguay. Authors thank authorities of Parques Nacionales of Argentina and staff of Parque Nacional El Palmar for the authorization and help with field work at the park. This English version of this work was edited by Adrian Burton. Luciano Gutiérrez facilitated the access to the ANCAP and Jesuita Quarries.

\section{References}

Alonso-Zarza, A.M., 2003. Palaeoenvironmental significance of palustrine carbonates and calcretes in the geological record. Earth Science Reviews 60, 261-298.

Alonso-Zarza, A.J., Jones, B.J., 2007. Root calcrete formation on Quaternary karstic surfaces of Grand Cayman. Geologica Acta 5, 77-88.

Alonso-Zarza, A.M., Silva, P.G., 2002. Quaternary laminar calcretes with bee nests: evidences of small scale climatic fluctuations. Eastern Canary Islands, Spain. Palaeogeography, Palaeoclimatology, Palaeoecology 178, 119-135.

Alonso-Zarza, A.M., Wright, V.M., 2010a. Palustrine carbonates. In: Alonso-Zarza, A.M. Tanner, L.H. (Eds.), Carbonates in Continental Settings: Facies, Environments and Processes: Developments in Sedimentology, 61. Elsevier, Amsterdam, pp. 103-132.

Alonso-Zarza, A.M., Wright, V.P., 2010b. Calcretes. In: Alonso-Zarza, A.M., Tanner, L.H (Eds.), Continental Carbonates. Facies, Environments and Processes: Developments in Sedimentology, 61. Elsevier, Amsterdam, pp. 225-267.

Alonso-Zarza, A.M., Calvo, J.P., García del Cura, M.A., 1992. Palustrine sedimentation and associated features - grainification and pseudo-microkarst - in the Middle Miocene (Intermediate Unit) of the Madrid Basin, Spain. Sedimentary Geology 76, 43-61.

Alonso-Zarza, A.M., Dorado-Valiño, M., Valdeolmillos-Rodríguez, A., Ruiz-Zapata, M.B., 2006. A recent analogue for palustrine carbonate environments: the Quaternary deposits of Las Tablas de Daimiel wetlands, Ciudad Real, Spain. In: Alonso-Zarza,A.M. Tanner, L.H. (Eds.), Paleoenvironmental Record and Applications of Calcretes and Palustrine Carbonates: Geological Society of America, Special Paper, 416, pp. 153-168.

Armenteros, I., Huerta, P., 2006. The role of clastic sediment influx in the formation of calcrete and palustrine facies: a response to paleogeographic and climatic conditions in the southeastem Tertiary Duero basin (northern Spain). In: Alonso-Zarza, A.M., Tanner, L.H. (Eds.), Paleoenvironmental Record and Applications of Calcretes and Palustrine Carbonates: Geological Society of America, Special Paper, 416, pp. 119-132.

Armenteros, I., Daley, B., García, E., 1997. Lacustrine and palustrine facies in the Bembridge Limestone (late Eocene, Hamshire Basin) of Isle of Wight, southern England. Palaeogeography, Palaeoclimatology, Palaeoecology 128, 111-132.

Bellosi, E.S., Genise, J.F., González, M., 2004. Origen y desmantelamiento de lateritas paleógenas del sudoeste del Uruguay (Formación Asencio). Revista del Museo Argentino de Ciencias Naturales 6, 25-40.

Bellosi, E.S., Iaza, J., Sánchez, M.V., Genise, J.F., 2010. Ichnofacial analysis of the Sarmiento Formation (Middle Eocene-Lower Miocene) at Gran Barranca, Central Patagonia. In: Madden, R., et al. (Ed.), The Paleontology of Gran Barranca: Evolution and Environmental Change through the Middle Cenozoic of Patagonia. Cambridge University Press, London, pp. 306-316.

Bossi, J., 1966. Geología del Uruguay: Colección Ciencias, 2. Universidad de la República, Departamento de Publicaciones, pp. 1-164.

Bossi, J., Navarro, R., 1991. Geología del Uruguay. Departamento de Publicaciones de la Universidad de la República, Montevideo. 966 pp.

Bossi, J., Ferrando, L.A., Fernández, A.N., Elizalde, G., Morales, H., Ledesma, J.J., Carballo, E., Medina, E., Ford, I., Montaña, J.R., 1975. Carta Geológica del Uruguay. Ediciones Oficiales Técnicas, Montevideo. $32 \mathrm{pp}$

Bustillo, M.A., 2010. Silicification of continental carbonates. In: Alonso-Zarza, A.M., Tanner L.H. (Eds.), Carbonates in Continental Settings: Geochemistry, Diagenesis and Applications: Developments in Sedimentology, 62. Elsevier, Amsterdam, pp. 153-178.

Bustillo, M.A., Alonso-Zarza, A.M., 2007. Overlapping of pedogenesis and meteoric diagenesis in distal alluvial and shallow lacustrine deposits in the Madrid Miocene Basin, Spain. Sedimentary Geology 198, 255-271.

Caorsi, J.H., Goñi, J.C., 1958. Geología Uruguaya. Boletín del Instituto de Geología del Uruguay $37,1-73$

Chebli, G.A., Tófalo, R., Turzzini, G.E., 1989. Mesopotamia. In: Chebli, G.A., Spalletti, LA (Eds.), Cuencas Sedimentarias Argentinas: Serie Correlación Geológica, 6. Universidad Nacional de Tucumán, pp. 79-100.

Daners, G., Guerstein, R., 2004. Dinoflagelados del Maastrichtiense-Paleógeno en la Formación Gaviotín, Cuenca de Punta del Este. In: Veroslavsky, G., Ubilla, M., Martínez, S. (Eds.), Cuencas sedimentarias de Uruguay: Geología, Paleontología y Recursos Naturales. Cenozoico, DIRAC, Universidad de la República, Facultad de Ciencias, Montevideo, pp. 37-62. 
Deocampo, D.M., 2010. The geochemistry of continental carbonates. In: Alonso-Zarza, A.M., Tanner, L.H. (Eds.), Carbonates in Continental Settings: Geochemistry, Diagenesis and Applications: Developments in Sedimentology, 62. Elsevier Amsterdam, pp. 1-59.

Dunagan, S.P., Driese, S.G., 1999. Control of terrestrial stabilization on late Devonian palustrine carbonate deposition: Catskill Magnafacies, New York, U.S.A. Journal of Sedimentary Research 69, 772-783.

Edwards, N., Jarzembowski, E.A., Pain, T., Daley, B., 1998. Cocoon-like trace fossils from the lacustrine-palustrine Bembridge Limestone Formation (Late Eocene), Southern England. Proceedings of the Geologists' Association 109, 25-32.

Esteban, M., Klappa, C.F., 1983. Subaerial exposure environments. In: Scholle, P.A., Bebout, D.G., Moore, C.H. (Eds.), Carbonate Depositional Environments: American Association of Petroleum Geologists Memoir, 33, pp. 1-96.

Frenguelli, J., 1930. Apuntes de geología uruguaya. Boletín Instituto de Geología y Perforaciones (Uruguay) 11, 1-47.

Freytet, P., 1973. Petrography and paleo-environment of continental carbonate deposits with particular reference to the Upper Cretaceous and Iower Eocene of Ianguedoc (Southern France). Sedimentary Geology 10, 25-60.

Freytet, P., 1984. Ies sédiments lacustres carbonatés et leurs transformations par émersion et pédogenèse. Importance de leur identification pour les reconstitutions paéogéographiques. Bulletin des Centres de Recherche Exploration-Production ElfAquitain@@e,223-246.

Freytet, P., Plaziat,J.C., 1982. Continental Carbonate Sedimentation and Pedogenesis - Iate Cretaceous and Early Tertiary of Southern France: Contributions to Sedimentology, 12. E. Schweizerbart'sche Verlagsbuch handlung, Stuttgart. 213 pp.

Freytet, P., Verrecchia, E.P., 2002. Lacustrine and palustrine carbonate petrography: an overview. Journal of Paleolimnology 27, 221-237.

Genise, J.F., 1999. Paleoicnología de Insectos. Revista de la Sociedad Entomológica Argentina 58 (1-2), 104-116.

Genise, J.F., Edwards, N., 2003. Ichnotaxonomy, origin, and paleoenvironment of Quaternary insect cells from Fuerteventura, Canary Islands, Spain. Journal of the Kansas Entomological Society 76, 320-327.

Genise, J.F., Laza, J.H., Fernández, W., Frogoni, J., 2002. Cámaras pupales fósiles de coleópteros: el icnogénero Rebuffoichnus Roselli. Revista del Museo Argentino de Ciencias Naturales 4, 159-165

Genise, J.F., Bellosi, E.S., González, M.A., 2004. An approach to the description and interpretation of ichnofabrics in palaeosols. In: McIlroy, D. (Ed.), The Application of Ichnology to Palaeoenvironmental and Stratigraphic Analysis: Geological Society of London Special Publications, 228, pp. 355-382.

Genise, J.F., Melchor, R.N., Bellosi, E.S., Verde, M., 2010. Invertebrate and vertebrate trace fossils from continental carbonates. In: Alonso-Zarza, A.M., Tanner, L.H. (Eds.), Carbonates in Continental Settings: Continental Carbonates. Facies, Environments and Processes: Developments in Sedimentology, 61. Elsevier, Amsterdam, pp. 319-369.

Gierlowski-Kordesch, E.H., 2010. Lacustrine carbonates. In: Alonso-Zarza, A.M., Tanner, L.H. (Eds.), Carbonates in Continental Settings: Facies, Environments and Processes: Developments in Sedimentology, 61. Elsevier, Amsterdam, pp. 1-102.

González, M.G. 1999. Los paleosuelos de la Formación Laguna Palacios (Cretácico Superior) de Patagonia y la Formación Asencio (Cretácico Superior-Terciario Inferior) de Uruguay. Boletim do $5^{\circ}$ Simposio sobre o Cretáceo do Brasil, pp. 65-70.

Goso, H., Bossi, J., 1966. El Cenozoico. In: Bossi, J. (Ed.), Geología del Uruguay. Departamento de Publicaciones de la Universidad de la República, Montevideo, pp. 259-301.

Goso-Aguilar, C., 1999. Análise estratigráfica do Grupo Paysandú (Cretáceo) na Bacia do Litoral Uruguay. Tese de Doutoramento IGCE-UNESP, Río Claro, Brasil. 184 pp.

Goso-Aguilar, C., Perea, D., 2003. El Cretácico post-basáltico de la Cuenca Litoral del Río Uruguay: geología y paleontología. In: Veroslavsky, G., Ubilla, M., Martínez, S. (Eds.), Cuencas Sedimentarias de Uruguay: geología, paleontología y recursos minerales - Mesozoico. Facultad de Ciencias, Montevideo, pp. 141-169.

Herbst, R., 1980. Consideraciones estratigráficas y litológicas sobre la Formación Fray Bentos (Oligoceno Inf-Medio) de Argentina y Uruguay. Revista de la Asociación Geológica Argentina 35, 308-317.

Herbst, R., Santa Cruz, J.N., 1985. Mapa litoestratigráfico de la provincia de Corrientes. D'Orbygniana 2, 1-51

Houston, T.F., 1987. Fossil brood cells of stenotritid bee (Hymenoptera, Apoidea) from the Pleistocene of South Australia. Transactions of the Royal Society of South Australia 3, 93-97.

Huerta, P., Armenteros, I., 2005. Calcrete and palustrine assemblages on a distal alluvialfloodplain: a response to local subsidence (Miocene of the Duero Basin, Spain). Sedimentary Geology 177, 235-270.

Jones, G., 1956. Memoria explicativa y mapa geológico de la región oriental de Departamento de Canelones. Boletín del Instituto Geológico del Uruguay34, 1-193.

Jones, B., 1992. Construction of spar calcite crystals around spores. Journal of Sedimentary Petrology 62, 1054-1057.

Jutras, P., Utting, J., Mcleod,J., 2007. Link between long-lasting evaporitic basins and the development of thick massive phreatic calcrete hardpans in the Mississippian Windsor and Percé Groups of eastern Canada. Sedimentary Geology 201, 75-92.

Khalaf, F.I., Gaber, A.S., 2008. Occurrence of cyclic palustrine and calcrete deposits within the Lower Pliocene Hagul Formation, East Cairo District, Egypt. Journal of African Earth Sciences 51, 298-312.

lambert, R., 1939. Memoria explicativa de un mapa geológico de los terrenos sedimentarios y rocas efusivas del Departamento de Durazno. Boletín del Instituto de Geología del Uruguay 25, 1-37.

Iambert, R., 1940a. Memoria explicativa de la carta geológica de reconocimiento del departamento de Paysandú y alrededores de Salto. Boletín del Instituto Geológico del Uruguay 27, 1-41

Iambert, R., 1940b. Memoria explicativa del mapa geológico del departamento de Río Negro. Boletín del Instituto Geológico del Uruguay 28, 1-33. edimentary attributes and implications for concepts of carbonate sequence stratigraphy. Journal of Sedimentary Research 76, 292-309.

Martínez, S., Veroslavsky, G., 2004. Registros continentales no depositacionales del Terciario temprano. In: Veroslavsky, G., Ubilla, M., Martínez, S. (Eds.), Cuencas Sedimentarias de Uruguay: geología, paleontologíay recursos minerales - Cenozoico. Facultad de Ciencias, Montevideo, pp. 63-82.

Martínez, S., Veroslavsky, G., Verde, M., 1997. Primer registro del Paleoceno en el Uruguay: paleosuelos calcáreos fosiliferos en la Cuenca de Santa Lucía. Revista Brasileira de Geociencias 27, 295-302.

Martínez, S., Veroslavsky, G., Verde, M., 2001. Paleoecología de los paleosuelos calcáreos fosiliferos ("Calizas del Queguay" Paleoceno) de las regiones sur y litoral oeste de Uruguay. Actas del XI Congreso Latinoamericano de Geología y III Congreso Uruguayo de Geología. 4 pp., CD-ROM

Mazzullo, S. J., Birdwell, B.A., 1989. Syngenetic formation of grainstones and pisolites from fenestral carbonates in peritidal settings. Journal of Sedimentary Petrology59, 605-611.

Melchor, R.N., Genise, J.F., Miquel, S., 2002. Ichnology, sedimentology and paleontology of Eocene calcareous paleosols from a palustrine sequence, south west Ia Pampa, Central Argentina. Palaios 17, 16-35.

Mones, A., 1979. Terciario del Uruguay. Revista de la Facultad de Humanidades y Ciencias (Ciencias de la Tierra) 1, 1-28.

Nash, J.D., Ullyoot, J.S., 2007. Silcrete. In: Nash, D.J., McLaren, S.J. (Eds.), Geochemical Sediments and Landscapes. Blackwell Publishing, Oxford, pp. 95-143.

Oviatt, C.G., Madsen, D.B., Schmitt, D.N., 2003. Iate Pleistocene and early Holocene rivers and wetlands in the Bonneville basin of western North America. Quaternary Research 60, 200-210

Pazos, P., Tófalo, O.R., Gonzalez, M., 1998. Ia Paleosuperficie Yapeyú: Significado estratigráfico y paleoambiental en la evolución del Cretácico Superior del Uruguay. $2^{*}$ Congreso Uruguayo de Geología, Actas. Punta del Este, pp. 59-63.

Platt, N.H., 1989. Lacustrine carbonates and pedogenesis: sedimentology and origin of palustrine deposits from the Early Cretaceous Rupelo Formation. W Cameros Basin, N Spain. Sedimentology 36, 665-684.

Platt, N.H., Wright, V.P., 1992. Palustrine carbonates at the Florida Everglades: towards an exposure index for the fresh-water environment. Journal of Sedimentary Petrology 62, 1058-1071.

Preciozzi, F., Spoturno, J., Henizen, W. y Rossi, P. 1985. Memoria explicativa de la Cata Geológica del Uruguay in escala 1:500.000. DINAMIGE, Montevideo. 90 pp.

Retallack, G.J., 1984. Trace fossils of burrowing beetles and bees in an Oligocene paleosol, Badlands National Park, South Dakota. Journal of Paleontology 58 , 571-592.

Reuter, M., Piller, W.E., Harzhauser, M., Kroh, A., Berning, B., 2009.A fossil everglades-type marl praire and its paleoenvironmental significance. Palaios $24,747-755$.

Roselli, F.L, 1939. Apuntes de geología y paleontología uruguaya. Sobre insectos de Cretácico del Uruguay o descubrimiento de admirables instintos constructivos de esa época: Boletín de la Sociedad Amigos de las Ciencias Naturales "Kraglievich-Fontana", 1 , pp. $72-102$.

Semeniuk, V., Meagher, T.D., 1981. The geomorphology and surface processes of the Australind-Leschenault Inlet coastal area. Journal of the Royal Society of Western Australia 64, 33-51.

Serra, N., 1945. Memoria explicativa del mapa geológico del departamento Soriano. Boletín del Instituto Geológico del Uruguay 32, 1-42.

Sprechmann, P., Bossi, J., Da Silva, J., 1981. In: Volkheimer, W., Musacchio, E. (Eds.), Cuencas del Jurásico y Cretácico del Uruguay: Cuencas Sedimentarias del Jurásico y Cretácico de América del Sur, 1, pp. 239-270.

Stokes, M., Nash, D.J., Harvey, A.M., 2007. Calcrete 'fossilisation' of alluvial fans in SE Spain: The roles of groundwater, pedogenic processes and fan dynamics in calcrete development. Geomorphology 85, 63-84.

Summerfield, M.A., 1983. Silcrete. In: Goudie, A.S., Pye, K. (Eds.), Chemical Sediments and Geomorphology. London, Academic Press, pp. 59-91.

Tófalo, O.R., Morrás, H.J.M., 2009. Evidencias paleoclimáticas en duricostras, paleosuelos y sedimentitas silicoclásticas, del Cenozoico de Uruguay. Revista de la Asociación Geológica Argentina 65, 674-686.

Tófalo, O.R., Pazos, P.J., 2010. Paleoclimatic implications (Iate Cretaceous-Paleogene) from micromorphology of calcretes, palustrine limestones and silcretes, southern Paraná Basin, Uruguay. Journal of South American Earth Sciences 29, 665-675.

Tofalo, O.R., Pazos, P.J., Sánchez, L, de Santa Ana, H., Alonso, S., 2001. Caracterización micromorfológica de calcretes, "Calizas de Queguay", Departamento Paysandú, Uruguay. 11 Congreso Latinoamericano de Geología y Congreso Uruguayo de Geología, Montevideo, pp. 5-24.

Veroslavsky, G., De Santa Ana, H., 2004. Calizas del Queguay: génesis y potencial económico. In: Veroslavsky, G., Ubilla, M., Martínez, S. (Eds.), Cuencas Sedimentarias de Uruguay. Geología, Paleontología y Recursos Naturales. : Cenozoico. DIRAC Universidad de la República, Facultad de Ciencias, Montevideo, pp. 269-296.

Veroslavsky, G., Martínez, S., 1996. Registros no depositacionales del Paleoceno-Eoceno del Uruguay: nuevo enfoque para viejos problemas. Revista de la Universidade Guarulhos, (Serie Geociencias) 1 (3), 32-41.

Veroslavsky, G., Martínez, S., de Santa Ana, H., 1997. Calcretas de aguas subterraneas y pedogénicas: génesis de los depósitos carbonáticos de la Cuenca de Santa Lucía, sur del Uruguay (Cretacico Superior?-Paleógeno). Revista de la Asociación Argentina de Sedimentología 4 (1), 25-35.

Verrecchia, E.P., 2007. Lacustrine and palustrine geochemical sediments. In: Nash, D.J., McLaren, S.J. (Eds.), Geochemical Sediments and Landscapes. Blackwell Publishing Oxford, pp. 298-329.

Walther, K., 1931. Sedimentos gelíticos y clastogelíticos del Cretácico Superior y Terciario uruguayos. Boletín del Instituto Geológico del Uruguay 13, 1-94.

Wright, V.P., 1989. Terrestrial stromatolites: a review. Sedimentary Geology 65, 1-13. 
Wright, V.P., 2007. Calcretes. In: Nash, D., McLaren, S. (Eds.), Geochemical Sediments and Landscapes. Willey-Blackwell, pp. 10-45.

Wright, V.P., Platt, N.H., 1995. Seasonal wetland carbonate sequences and dynamic catenas: a reappraisal. Sedimentary Geology 99, 65-71.

Wright, V.P. Tucker, M.E., 1991. Calcretes: an introduction. In: Wright, V.P., Tucker, M.E. (Eds.), Calcretes: IAS Reprint Series, 2. Blackwell Scientific Publications, Oxford, pp. $1-22$.

Wright, V.P., Platt, N.H., Wimbledon, W., 1988. Biogenic laminar calcretes: evidence of calcified root mat horizons in palaeosols. Sedimentology 35, 603-620.
Wright, V.P., Platt, N.H., Marriot, S.B., Beck, V.H., 1995. A classification of rhizogenic (rootformed) calcretes, with examples from the Upper Jurassic-Iower Carboniferous of Spain and Upper Cretaceous of southern France. Sedimentary Geology 100, 143-158. Wright, V.P., Alonso-Zarza, A.M., Sanz, M.E., Calvo, J.P., 1997. Diagenesis of Late Miocene micritic lacustrine carbonates, Madrid Basin, Spain. Sedimentary Geology 114, 81-95. 